\title{
Intensified mid-Holocene floods recorded by archeomalacological data and resilience of first farming groups of the Carpathian Basin
}

\author{
Sándor Gulyás ${ }^{1}$ (1) • Balázs Nagy ${ }^{1} \cdot$ Pál Sümegi ${ }^{1,2} \cdot$ Gabriella Schöll-Barna $^{3} \cdot$ Attila Demény $^{3}$
}

Received: 23 April 2019 / Accepted: 17 June 2020

(C) The Author(s) 2020

\begin{abstract}
One of the most significant cultural transformations in European prehistory occurred in the middle of the 6th millennium BC in the heart of the Carpathian Basin. The northward expansion of Mediterranean farming groups (Starčevo-Körös-Criș cultural complex) halted and underwent a complete transformation giving rise to a new cultural group carrying an altered form of Neolithic traditions onward to Europe. This transformation is restricted to sites along a boundary found in the heart of the basin, north of which unfavorable ecological conditions hampered a long-term engagement in a Mediterranean type of agriculture. The majority of Early Neolithic Körös sites in eastern Hungary are confined to the alluvial plain of the Tisza River prone to natural biannual flooding. These wetland conditions were marginal for early farmers as it contained several elements that were hostile for herded animals and these groups were not adopted to cope with. Körös Culture pastoralists responded to these challenges posed by the new environment by complementing their diet with opportunistically exploited wild resources. This type of resilience of the first farmers seen in the alteration of traditional subsistence strategies was simply attributed to the static hostile conditions of the environment alone. Influence of dynamic changes in the hydrology has not been studied and documented so far. This paper presents a multiproxy archeomalacological approach to establish a mid-Holocene flood record in Southern Central Europe and assess the potential impacts of flood frequencies, climate change-induced higher floods on economic, societal development of the first farming groups from the heart of the Carpathian Basin. Based on our findings, intensified use of second-line subsistence resources marking resilience is coeval with intensified flooding during the second phase of cultural evolution preceding transformation. This marked transformation could have been traced regionally as well along the referred northern distribution line and is coeval with the initial phase of a minor climatic perturbation refered to as the IRD 5.b event. The southward expansion of cold waters in the North Atlantic yielded intensive cyclonic activity bringing more rain and cold weather to W Europe. In Hungary, higher continentality provided by the basin setting preserved warmer conditions. Nevertheless, increased rainfall onto the watershed of major rivers triggered heightened floods.
\end{abstract}

Keywords Multiproxy paleoecological analysis · Flooding $\cdot$ Cultural transformation $\cdot$ Climate change $\cdot$ Early Neolithic Carpathian Basin

Electronic supplementary material The online version of this article (https://doi.org/10.1007/s12520-020-01120-3) contains supplementary material, which is available to authorized users.

Sándor Gulyás

gulyas.sandor@geo.u-szeged.hu

1 Department of Geology and Paleontology, University of Szeged, Egyetem u.2-6, Szeged 6722, Hungary

2 Institute of Archeology, Hungarian Academy of Sciences, Úri u. 49, Budapest 1014, Hungary

3 Institute of Geochemistry, Hungarian Academy of Sciences, Budapest, Hungary

\section{Introduction}

Foraging is among the most ancient subsistence forms characterizing human communities before $10 \mathrm{kys}$ in general. However, the introduction of farming and herding by no means meant a complete disappearance of this lifestyle among the very first food-producing societies. Foraging must have remained an important part of daily subsistence (Childe 1956; Legge and Rowley-Conwy 1987; Plug and Voight 1985; Szuter and Bayham 1989; Zvelebil and Dolukhanov 1991), probably because flexible opportunistic agricultural systems, like reliance on multiple resources aimed at diversifying landscape capital, offer an advantage of greater economic security if 
there are fluctuations in the weather, water supply, or during periodic die-offs of crop yields (Messerli et al. 2000; Pfister et al. 1999; Pfister 2001; Redman 2005; Haldon and Rosen 2018; Xu et al. 2019; Yang et al. 2019). Fluctuations in available food sources are most likely the result of a complex interplay of various environmental (climatic) (Carré et al. 2009; Coombes and Barber 2005) and social (behavioral) factors (Messerli et al. 2000; Speth 1990; Spielmann 1986). Hostility of the environment or rapid, sudden deterioration in natural endowments may put forth an increased reliance on second-line resources in subsistence like foraging or hunting (Broughton 1999; Polyak and Asmerom 2001; Butler and Campbell 2004; Berger and Guilaine 2009; Weninger et al. 2006; Drysdale et al. 2006; Weiberg and Finné 2018; Xu et al. 2019). The nature of responses deployed to these is dependent on the level of resilience or vulnerability of the given society seen in its ability to face changes (Redman 2005; Kuper and Kropelin 2006; Pfister and Brazdil 2006; Berger and Guilaine 2009; Salisbury and Bácsmegi 2013; Haldon and Rosen 2018; Weiberg and Finné 2018; Xu et al. 2019; Yang et al. 2019). It entails the knowledge of local endowments and the distribution of potentially available subsistence resources which can easily be brought online in case of a socio-economic crisis (Rockman 2003; Meltzer 2003; Anthony 1990; Messerli et al. 2000; Pfister et al. 1999; Redman 2005; Carré et al. 2009; Nagaoka 2002, 2005; Gulyás 2011; Gulyás and Sümegi 2004, 2011a,b, 2012a,b; Gulyás et al. 2007). It also determines whether or not environmental perturbations can be devastating for social development (Redman 2005; Haldon and Rosen 2018; Weiberg and Finné 2018; Xu et al. 2019; Yang et al. 2019).

One of the most significant cultural transformations in European prehistory occurred in the middle of the 6th millennium BC in the heart of the Carpathian Basin (Kutzián 1944; Kalicz 1970; Raczky 1978, 1983, 1986; Raczky et al. 2010; Sümegi and Kertész 1998, 2001). The northward expansion of Mediterranean farming groups (Starčevo-Körös-Criş Cultural Complex) came to a halt and underwent a complete transformation both in subsistence pattern and material culture giving rise to a new cultural group (Linear Pottery Culture), one variant $^{1}$ of which spread the Neolithic package to the rest of Western and Northern Europe (Kalicz 1970; Raczky 1978, 1983, 1986; Bánffy 2000, Bánffy 2004a, 2004b, 2006; Whittle et al. 2002; Whittle 2007; Oross and Bánnfy 2009). On the scale of the entire basin, this happened along a clearly

\footnotetext{
${ }^{1}$ AVK and DVK are contemporary cultural groups of regional variants of the Middle Neolithic Linear Pottery Culture, DVK (Transdanubian Linear Pottery Culture) is restricted to Western Hungary and known to spread the Neolithic package to the rest of Western Europe, and AVK (Alföld Linear Pottery Culture) occupied the NE part of the Great Hungarian Plain (Kutzián 1944; Kalicz 1970; Raczky 1978; Raczky 1983; Raczky et al. 2010; Bánffy 2000; Bánffy 2004a; Bánffy 2004b, 2006; Whittle et al. 2002; Whittle 2007; Oross and Bánnfy 2009; Bánffy and Oross 2010).
}

discernible boundary with an approximately NE-SW orientation, north of which climatic, soil, and vegetation conditions hampered the long-term engagement in a Mediterranean type of agriculture based on cultivation of warmth-loving plants and caprines (Fig. 1). This boundary was nominated the Central European Balkanic Agroecological Barrier (Sümegi and Kertész 1998; Sümegi 2001, 2003a, 2003b, 2006, 2008; Raczky et al. 2010). Surprisingly, the mentioned transformation is observable in sites along the referred marginal distribution areas of of the Körös Culture. Classical Mediterranean farming remained relatively unaltered in the southern distribution areas (Whittle et al. 2002; Whittle 2004; Raczky et al. 2010).

Thanks to new ${ }^{14} \mathrm{C}$ data and archeological finds (Domboróczky 2003, Domboróczki 2010; Bánffy and Oross 2010; Oross and Siklósi 2010) we now have a relatively good overview of how the representatives of the first farmers (Körös Culture) spread north in the Great Hungarian Plains (GHP). The Starčevo Culture crossed the Lower Danube around $6200 \mathrm{cal} \mathrm{BC}$. The Körös Culture reached the Maros around $6000 \mathrm{cal}$ BC and it took another 100-150 years (5900$5850 \mathrm{cal} \mathrm{BC)} \mathrm{for} \mathrm{them} \mathrm{to} \mathrm{reach} \mathrm{the} \mathrm{branches} \mathrm{of} \mathrm{the} \mathrm{Körös}$ River and the Middle Tisza Region (Raczky 1986; Raczky et al. 2010; Domboróczky 2003, 2005). The final colonization of the Upper Tisza Region in the northeastern parts of the GHP occurred between 5770 and 5530 cal BC (Whittle 2007; Whittle et al. 2002; Domboróczky 2003, 2005, Domboróczki and Raczky 2010; Raczky et al. 2010).

The majority of Early Neolithic (Körös Culture) sites in eastern Hungary are confined to the alluvial plain of the Tisza, Hungary's second largest stream and its tributaries (Roberts 1998; Nandris 1972; Kosse 1979; Sherratt 1982; Sümegi 2003b). The area of the Great Hungarian Plain preceding the nineteenth century river regulation measures was frequently inundated by biannual floods of the Tisza and its tributaries creating vast wetland areas, most of which remained under water for the major part of the year. Although flooding is a substantial risk for settling communities, their contribution to the ecosystem functioning is crucial. These iterative floods on the one hand ensured a constant supply of organic-rich matter onto the floodplain. On the other hand, they also served to compensate for loss in water supply attributed to the climatic endowments of the area, since the heart of the basin is considered to be the driest part of Central Europe thanks to the extremely high continentality rates (annual rainfall below $300 \mathrm{~mm}$ during growth season). Thus, the selection of a floodplain environment for settling, despite the risk of normal seasonal flooding, has numerous advantages as these complex habitats with a diverse natural flora and fauna, and soils provide multiple sources of subsistence and permanent water supply (Gardner 2005; Gillings 2007; Raczky et al. 2010). Conversely, wetland conditions were marginal for early farmers engaged in a Mediterranean type economy based 


\section{MDDLE NEOLIHIC GROUPS Central European [Transdanubian] LBK [DUK] Alföld LBK [AVK] \\ Vinca Gulture Sopot Gulture EARIY NEOLITHE GROUPS} Starcevo-Körös-Gris Gultures northern boundary of distribution
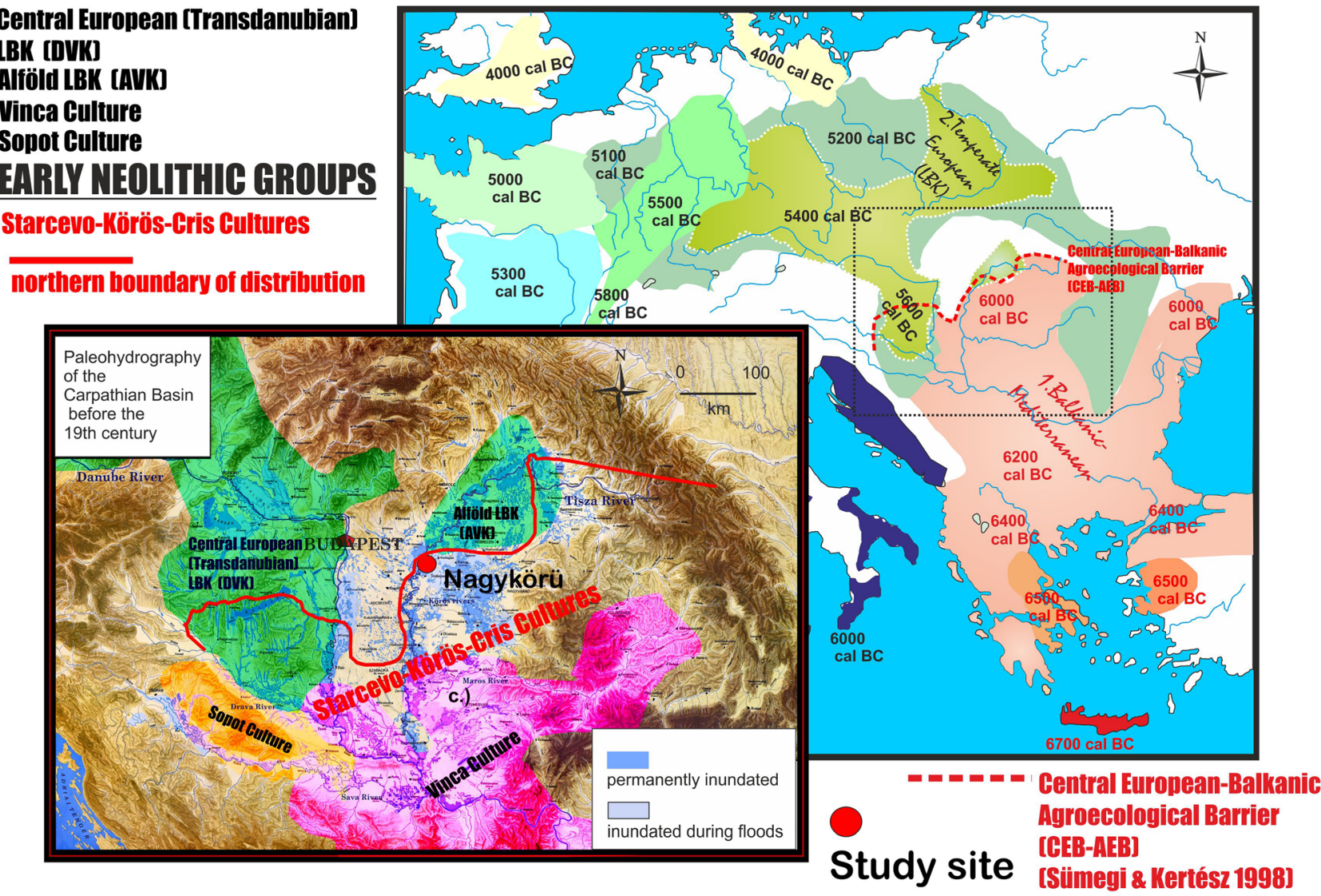

Fig. 1 The spread of agriculture in Europe and the first farming cultures of the Carpathian Basin (modified after Burger et al. 2006, Groenborn 2019, Makkay and Starnini 2008, Bánffy and Oross 2010, Jakucs et al. 2016. Our study site of Nagykörü is also marked)

on herding caprines. It contained several elements that were hostile for herded animals and these groups were not adopted to cope with (Raczky et al. 2010). Signs of water-induced stress are clearly attested by paleopathological observations made on small ruminant bones from numerous Körös Culture sites showing marks of arthritic inflammation and osteoporosis of foot bones and skulls (Bartosiewicz 2005, 2006, 2007; Raczky 2012; Raczky et al. 2010). Sheep fetal remains recovered from the Körös site of Nagykörü, found at the culture's northern distribution line, is another indicator of environmental pressure on ewe causing miscarriage (Bartosiewicz 2005, 2006, 2007; Raczky 2012; Raczky et al. 2010). Körös Culture pastoralists responded to these challenges posed by the new environment by complementing their diet with opportunistically exploited wild resources (Bartosiewicz 2005, 2006, 2007; Pike-Tay et al. 2004; Raczky 2012; Raczky et al. 2010, SFig. 1). In the Upper and Central Tisza Region, the Körös Culture settlements coexisted with the earliest ALP types between 5620 and $5530 \mathrm{cal} \mathrm{BC}$ forming a transitional region of the two cultures
(Domboróczky 2003, 2005; Domboróczki and Raczky 2010; Raczky et al. 2010). Thus, the earliest ALP in these areas along the northern frontier of the Körös Culture must have developed between 5620 and $5470 \mathrm{cal} \mathrm{BC}$. This period of overlap was relatively short implying a rapid transformation. There is a marked change in subsistence to animal husbandry and a decrease in second-line resources (Domboróczky 2003, 2005, Domboróczki and Raczky 2010; Raczky et al. 2010).

It is important to note that this type of resilience of the first farmers seen in the alteration of traditional subsistence strategies is only partially attributable to the unique, previously unknown conditions of the floodplain habitats. According to the available geoarcheological data from the Körös sites in the marginal zone of the culture's distribution area, settlements were gradually displaced onto flood-free natural highs (lagsurfaces) of the floodplain parallel with the evolution of the culture (Sümegi 2003b). This can clearly mark an adaptation to increased water levels on the floodplains reducing social and economic areas. So far, however, the general hostility of the environment alone was considered a major push factor in 
adaptation of the new farmers (Sümegi and Kertész 1998; Sümegi 2001, 2003a, 2003b, 2006, 2008; Raczky 2012; Raczky et al. 2010). The dynamic nature of climate-induced hydrological changes has not been considered or documented so far.

High-resolution, sub-centennial paleoenvironmental data reflecting local and regional endowments of terrestrial and riparian habitats near Körös sites along with potential temporal perturbations are generally lacking. The few studies available tackling the problem do not provide information on longterm temporal changes just a momentary uniform hydrological picture of the landscape at the time of the settlement (Sümegi 2003a, 2004, 2007; Sümegi and Molnár 2007; Sümegi et al. 2005; Whittle 2007; Gulyás 2011; Gulyás and Sümegi 2004; Gulyás and Sümegi 2012a, 2012b; Gulyás et al. 2007).

Thus, in order to see whether or not long-term climate induced potential hydrological transformations influenced human behavior, causing initially the introduction and later the abandonment of new second-line freshwater and wild resources into the diet with the emergence of the Alföld Linear Pottery Culture, new results of a multiproxy paleoecological analysis implemented on archeological mollusk material of a Körös site in the Middle Tisza region found in the referred marginal distribution area are presented here. The study site is dated from the first appearance of the Körös Culture to the period preceding the previously referred cultural transformation leading to the emergence of the Alföld variant of Linear Pottery Culture (Raczky et al. 2010; Gulyás 2011; Gulyás and Sümegi 2012a, 2012b; Gulyás et al. 2010; Moskal-del Hoyo 2013). Thus, our results provide an ideal temporal record of water quality changes in the surrounding floodplain on the one hand, since freshwater mollusks collected by humans characterize the quality of the water body from which they derive. Furthermore, they are also an excellent marker of socioeconomic response to environmental stress hallmarking the deployment of multifocal subsistence strategies in agriculturalist groups. Terrestrial mollusks on the other hand may shed light onto compositional changes in the vegetation near the sites themselves, as well as potential fluctuations in the local paleotemperature and humidity (Evans 1972; Sümegi 1989; Sümegi and Krolopp 2002). This way we can get a better overview of temporal climatic, hydrological changes of the riparian environment, and potential underlying causes from the first appearance to the transformation of the Körös culture group in the northern GHP.

\section{General characteristics of the study site}

The study site of Nagykörü-Orchard is located on the northern boundary of distribution of the Early Neolithic Körös culture in the Carpathian Basin (Raczky et al. 2010; Moskal-del Hoyo et al. 2010; Moskal-del Hoyo 2013). The site itself is found on a loess-covered ancient (Pleistocene) levee (92 m ASL) along the right banks of the River Tisza, Hungary's second largest stream about $25 \mathrm{~km}$ northeast of the city of Szolnok (Fig. 2a). The surrounding Holocene floodplain of the Tisza with an average elevation of $82 \mathrm{~m}$ is built up of a complex network of adjacent meander scars, oxbow-lakes, backswamps, islandlike lag-surfaces ${ }^{2}$, and abandoned channels of minor watercourses, which acted as floodwater drains during the Holocene (Fig. 2b).

Preceding the nineteenth century river regulations more than $60 \%$ of the area around the site enjoyed permanent water coverage. The geomorphological, as well as the recent climatic endowments of the area with enhanced continentality and relatively high temperatures during the growth period $\left(17.2^{\circ} \mathrm{C}\right)$, fundamentally determined the evolution of soil and vegetation types, as well as the hydrology of the area yielding a mosaic of plants and soils forming a hydroseries (Raczky et al. 2010; Moskal-del Hoyo et al. 2010, Moskal-del Hoyo 2013). The relatively higher continentality is seen in the high number of hours of sunshine to the area as well, favorable from the point of view of a Mediterranean-type of agriculture.

The studied shellfish material comes from a Körös test pit located on top of the referred natural high. Excavations initiated in 2003 were aimed at taking representative samples from the pit along a square of $3 \times 3 \mathrm{~m}$ and not to recover the entire pit itself (Fig. 2c) (Csányi 2003; Raczky et al. 2010; Raczky 2012; Moskal-del Hoyo 2013). However, block sampling along a vertical profile, plus absolute dating of most Körös block samples, enabled us to study temporal aspects of site evolution as well. Altogether, 9 block samples were taken to a depth of ca. $1.5 \mathrm{~m}$. The upper three blocks assigned to Feature 1 to a depth of $0.45 \mathrm{~m}$ (F1S1-F1S3) represent the modern soil. The underlying 6 blocks of Feature 2 (F2S4, F2S7, F2S813, F2S914, F2S1015, F2S1116) correspond to the material of the actual Körös test pit (Raczky 2012). Radiocarbon dating yielded an age of 5850-5620 cal BC at the level of $1 \sigma$ uncertainty $(p=0.68)$ generally used and accepted by archeologists (Fig. 2c) (Raczky et al. 2010; Gulyás 2011; Gulyás and Sümegi 2012a, 2012b; Gulyás et al. 2010; Moskal-del Hoyo et al. 2010, Moskal-del Hoyo 2013; Oross and Siklósi 2010). To provide better constraint on dates of site use start and abandonment at the $2 \sigma$ level of uncertainty, a new age model using dates listed in Oross and Siklósi (2010) was built in Oxcal 4.1. (Bronk Ramsey and Lee 2013), results of which are presented here. All input data were provided as ${ }^{14} \mathrm{C}$ y $\mathrm{BP}$ and the model used the northern hemisphere IntCal13 calibration curve (Reimer et al. 2014) (Fig. 2, STable 1). According to this new model, site use must have started between 6075 and 5872 cal BC years $(5963 \pm 63$ cal BC years, $p=0.954)$

\footnotetext{
$\overline{2}$ This concept was introduced by Pál Sümegi (Sümegi 2003a, 2003b, 2004; Sümegi et al. 2005; Sümegi and Molnár 2007).
} 

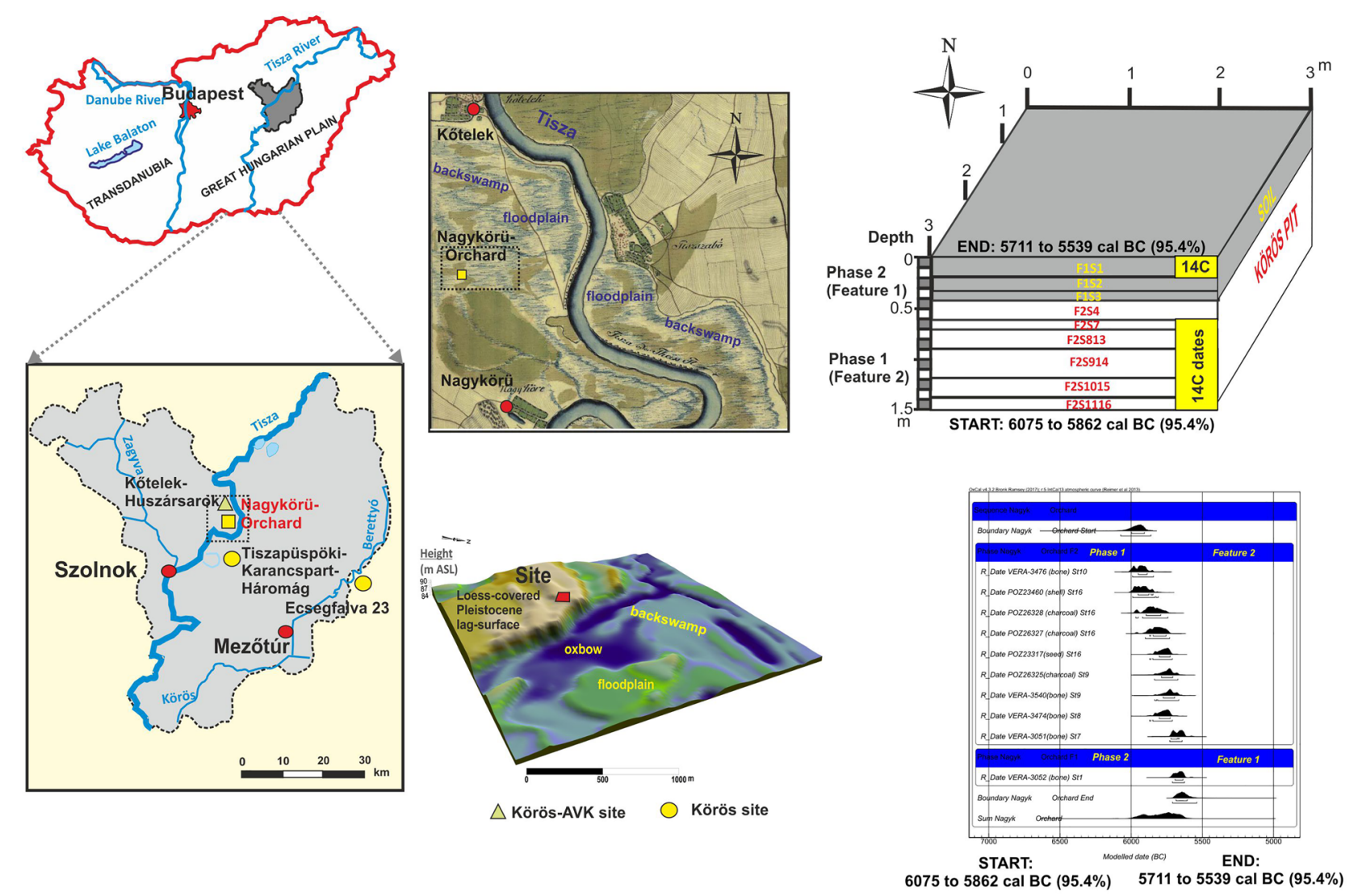

Fig. 2 Location of the study site of Nagykörü-Orchard

(STable 1). The first phase corresponding to the F2S7 block ended between 5730 and 5643 cal BC (5692 23 cal BC years, $p=0.954)$. The end of site use must be put between 5711 and $5539 \mathrm{cal} \mathrm{BC}(5634 \pm 47 \mathrm{cal} \mathrm{BC}$ years, $p=$ 0.954) (Figs. 2 and 3, STable 1). The first transitional AVK groups displaying a mix of Körös and AVK features and marking the time of the referred cultural and economic transformation appear at the nearby site of Kötelek-Huszársarok (Figs. 2a, b and 3) somewhere around 5720 and 5530 cal BC years (Raczky 1986; Raczky et al. 2010; Domboróczky 2003, 2005). Thus, our material with a span of ca. 330 years represents the period from the first appearance of the Körös culture in the Middle Tisza region up to its transformation period. The nearby Körös site of Ecsegfalva 23 (Fig. 2a), the most well-documented so far, falls into the second half of our site use of phase 1 preceding the time of cultural transformation (Fig. 3) (Whittle et al. 2002; Whittle 2007, 2012). Careful sampling and comparison of our findings with results gained for this latter contemporary site thus allowed for capturing the dynamics of hydrological changes on the floodplain during the referred transformation period at a scale of decades.

\section{Material and methods}

Faunal changes observable in the archeological material must be attributed to various factors, if we appreciate the human or cultural context of the material. Abundance of certain faunal elements in our freshwater shellfish material is the outcome of the complex interplay of various biotic (predation including humans) and abiotic ecological components (substrate conditions, hydraulic parameters, water temperature, $\mathrm{pH}$, bioproduction, sediment accumulation etc.) (Erman and Erman 1984; Byers and Broughton 2004; Wolverton 2005). Thus, changes observable in faunal abundances can indicate subsistence change and resource selection resulting from increased foraging pressure on the one hand. On the other hand, environmental change can also reduce the abundance of certain faunal elements independent of human predation. Thus, to resolve issues of temporal change observable in the studied archeofauna, a complex analysis of several lines of information is needed (Peacock and Seltzer 2008; Rustioni et al. 2007). In order to identify units of similar paleobiological content reflecting similar environmental or habitat conditions, the collective handling of ecological information of the studied taxa and faunal abundance values is needed. For this, 
Fig. 3 The chronology of the referred Körös sites including the study site of Nagykörü-Orchard and the nearby AVK site of Kőtelek-Huszársarok (data sources in parenthesis)

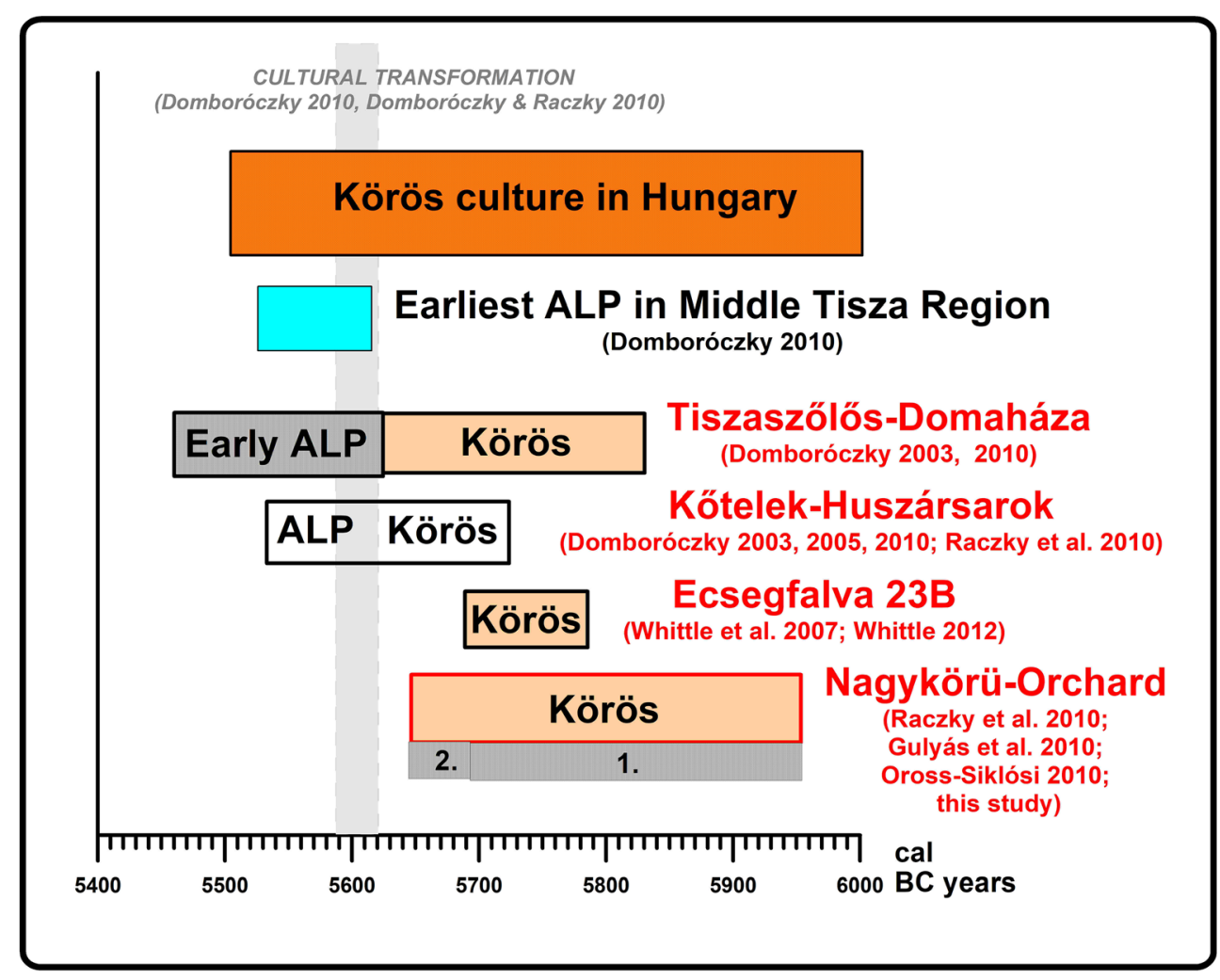

several widely adopted explorative multivariate statistical methods are known (Digby and Kempton 1987; Chatfield and Collins 1980; Davies 1998). In our work, DCA (detrended correspondence analysis) was implemented on a taxon/abudance data matrix per sample following the methods of Hill and Gauch Jr (1980), Behrensmeyer (1991), and Rustioni et al. (2007). Faunal composition based on abundance was determined using the measure minimum number of individuals (MNI) (Nichol and Wild 1984; Peterson 1989; Lyman 1994; Claasen 1998). Taphonomy of the shells was also considered via quantification of intact and broken shells as well as the ratio of right and left valves (Behrensmeyer and Hill 1980; Behrensmeyer et al. 2000). Ecological characteristics of the individual species were gleaned from studies of the modern fauna using the works of Sümegi (1989), Krolopp and Sümegi (1995), Sümegi and Krolopp (2002), Evans (1972), and Ložek (1964). Eigenvalues received during DCA were used to describe information expressed by the faunal composition of the sample as whole. Visual evaluation of the scatterplot enabled the interpretation of the ecological meaning of the received eigenvalues. Thus, the received axes were identified to reflect major ecological gradients, i.e., changes in water-velocity, substrate type in our interpretations.

In order to retain further ecological parameters of the studied aquatic habitats, shells were subjected to geochemical analysis. Some of the routinely recorded trace elements in shells are excellent markers or proxies of certain parameters of the studied water bodies. $\mathrm{Mn}^{2+}$ has been proposed as indicator of algal productivity (Vander Putten et al. 2000; Langlet et al. 2006, 2007; Caroll and Romanek 2008; Siegele et al. 2001; Lazareth et al. 2003) and as such an ideal proxy of the rate of dissolved oxygen in the water (Mutvei and Westermark 2001; Ravera et al. 2003, 2007; Caroll and Romanek 2008). $\mathrm{Fe}^{2+}$ and $\mathrm{Zn}^{2+}$ are soluble in relation to the acidity of the medium and as such may record fluctuations in the $\mathrm{pH}$ (Stumm and Morgan 1996; Mutvei and Westermark 2001). According to Lee and Wilson (1969) and Hill (1975), rivers with a larger discharge tend to be more dilute and as such relatively deprived of dissolved elements compared with rivers with a lower discharge. Consequently, a negative shift in general concentration values of trace elements may also reflect a transformation in discharge values of a fluvial system. Shells of the same mussel (Thick-shelled river mussel-Unio crassus Retzius 1788) and aquatic snail taxa (River snailViviparus acerosus (Bourguignat 1862)) were chosen for our geochemical analysis in order to avoid discrepancies deriving from taxon-specific incorporation of the studied elements. Samples were acid digested on hot plate following a modified procedure of Szöör et al. (1992) and Peacock and Seltzer (2008). Mn, Fe, and Zn concentrations were recorded using the flame AAS technique in a Perkin-Elmer AAS type 100 at the Department of Geology and Paleontology, University of Szeged, Hungary.

Another good source of information regarding paleoenvironmental conditions of freshwater systems is that of the concentration of certain isotopes as shown by numerous 
studies on modern marine and freshwater shellfish taxa (Dettman et al. 1999; Versteegh 2008; Caroll et al. 2006; Davies and Muehlenbachs 2001; Gustafson et al. 2007; Peacock and Seltzer 2008). Stable isotopes of oxygen and carbon were measured in selected shell samples at the Institute of Geochemistry, Hungarian Academy of Sciences using a Finnigan type 500 ICP-MS. Values are reported in per mil with reference to the VPDB standard.

Statistical analysis including Kruskall-Wallis test, similarity, and correlation analyses were performed following the methods of Sokal and Rohlf (1995) to explore and clarify the relationship among the gained variables. Statistical significance was assumed when $p<0.05$ and 0.01 , respectively (Hammer and Harper 2005).

\section{Results}

\section{Taxonomic composition of the fauna}

The studied material yielded 14,542 specimens of 8 freshwater ( 4 bivalve \& 4 gastropod) and 9 terrestrial taxa representing ca. 10,000 individuals. The ratio of mussels and snails was relatively the same (54.82 and $45.18 \%$, respectively) most likely attributable to the artificial nature of the deposit. The extremely low proportion of terrestrial taxa compared with the freshwater one $(2.78 \%)$ is another indication of the origin of the material. Elements with a preference for moving-water conditions (rheopylic) and a sandy substrate are dominant in the fauna $(81.38 \%)$. Conversely, the amount of those preferring standing or temporarily moving waters and a muddy substrate is almost negligible (18.62\%). The ratio of the rheophylic river snail (Viviparus acerosus (Bourguignat 1862)) dwelling on aquatic vegetation and that of the thickshelled river mussel (Unio crassus Retzius 1788) preferring a sandy substrate in our pit material is also relatively even (38.54 and 36.36\%), again reflecting the nature of the deposit. The amounts of snails populating minor ponds, great ramhorn snail-Planorbarius corneus (Linnaeus 1758), great pond snail-Lymnaea stagnalis (Linnaeus 1758), are also minimal $(0.15 \%)$ similarly to that of the pond-dweller pond mussel (Anodonta cygnea (Linnaeus 1755)) (1.19\%). They must have ended up in the deposit either as a side-product of fishing and shellfishing or natural colonization of the inundated pit as a result of an elevated groundwater table in case of the gastropods. The general composition of the entire fauna implies the development of a floodplain with a large variety of multiple ecotones of backswamps, oxbow lakes with a lush aquatic vegetation and a dominance of areas enjoying moving-water conditions and a sandy substrate (Fig. 2). The general composition of the terrestrial mollusk fauna indicates warm, balanced climatic conditions with mean July paleotemperatures around $22{ }^{\circ} \mathrm{C}$, slightly higher than the modern value in accordance with the concept of a climatic optimum. Roughly, half of the terrestrial fauna was given by hygrophilous elements inhabiting wet meadows and shady areas of forest steppes. The other half was given by xerophylous elements populating grasslands, so the duality of the terrestrial fauna also reflects a rather mosaic-like nature of the terrestrial environment of the natural high hosting the settlement regarding humidity and vegetation types similarly to the pattern seen in the aquatic fauna, but was it really a climatic optimum for the first settlers in all aspects? Bearing the general location of the site in mind, the inferred conditions of the riparian environment could have emerged only in a period hallmarked by immense iterative floods in general. From this aspect, it would be crucial to know whether or not these conditions prevailed during the entire history of the pit. The picture gets even more interesting when we look at the composition of the fauna by blocks.

If we examine the general distribution of freshwater bivalves and snails along the studied profile, we can clearly see that the ratio of them is relatively even in this case as well. However, the soil blocks (F1S1 to F1S3) and the lowermost two blocks of the Körös pit (F2S1015 \& F2S1116) are characterized by extremely low specimen numbers for all freshwater taxa in contrast to the other Körös pit blocks. This may imply that different subsistence strategies must have prevailed during the first phase of site evolution and the succeeding periods. In order to see whether the same pattern holds true for habitat conditions and as such may indicate interrelatedness with subsistence strategies, it was necessary to evaluate taxonomic composition of both mollusk fauna along the profile as well. As seen on Fig. 4, there is a relatively large scatter of samples along both axes of the DCA scatterplot marking the most important ecological gradients yielding the observed faunal composition of the freshwater fauna. Along Axis 1, rheophylic taxa are characterized by slightly positive eigenvalues close to zero $(<0.4)$. Conversely, elements with a preference for standing water or tolerating temporary moving water conditions are characterized by positive eigenvalues between 0.4 and 1.1. Thus, we may interpret this gradient as reflecting stream velocity on the floodplain. Conversely, there is a marked separation of freshwater gastropods dwelling in minor muddy ponds of the backswamp (eigenvalues $\sim 2$ ) from the rest of the taxa populating oxbow lakes and drainage channels of the floodplain in general (eigenvalues $\sim 0$ ) along Axis 2. Thus, this separation must be linked to differences in habitat types.

If we examine the distribution of the samples along the referred axes (Figs. 4 and 5), we can clearly see that the lowermost two blocks (F2S101 \& F2s1116) are characterized by high positive eigenvalues $(\sim 1.6)$. Conversely, the uppermost two blocks of the Körös pit (F2S4 \& F2S7) have eigenvalues around 0 . The blocks in between are somewhat outliers. Block F2S914 directly overlying the lowermost two blocks seems to 
a.)
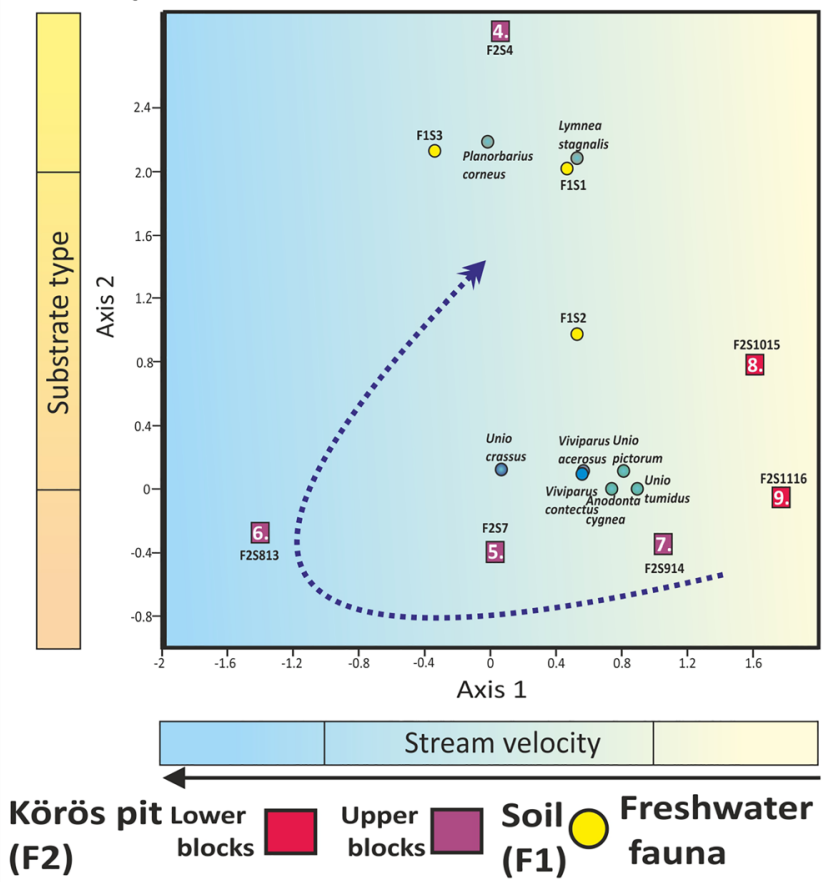

b.)

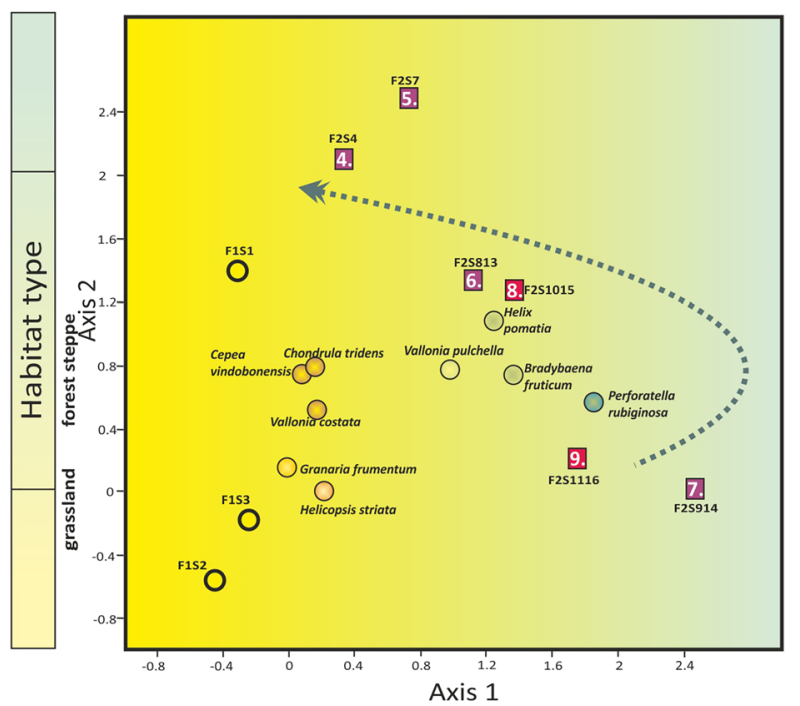

Moisture gradient

moving-water elements Terrestrial $\bigcirc \bigcirc$ hygrophylous standing or temporarily fauna $\bigcirc \bigcirc$ xerophylous moving-water elements ditch elements

Fig. 4 Results of multivariate ordination (DCA) of freshwater and terrestrial taxa Körös blocks (squares); soil blocks (light circles)

occupy an intermediate position between the contemporary block units (see Fig. 3 and chapter 2) with eigenvalues around 1. Conversely, the successive block of F2S813 has extremely low eigenvalues $(\sim-1.4)$. A similar pattern develops along Axis 2 with one exception of block F2S4. This difference must be attributed however to the larger proportion of the two pond dwelling snails in this material compared with the other blocks. Apart from this, the lowermost two blocks here again are clearly separated from the overlying blocks. The former has eigenvalues of 0 and 0.8 . Conversely, the latter is characterized by a uniform value $\sim-0.4$ indicating common conditions regarding the inferred environmental gradient along Axis 2, so it seems that the period captured by the lowermost two blocks was characterized by relatively calm conditions on the floodplain, hydraulically speaking with a dominance of muddy substrate. However, later markedly different conditions develop characterized by strong current parameters as seen in the similar trend of proxies gained to depict conditions of the riparian environment (Fig. 5). On the basis of this information, the emergence of immense iterative floods inferred from the general composition of the freshwater fauna could have been corroborated. Nevertheless, the observed temporal differences are in line with those seen for quantity of the harvested fauna, so the inferred shift in the quality of the riparian environment is seen in the alteration of subsistence strategies as well, implying a greater reliance on aquatic resources.
Terrestrial elements are separated along Axis 1 in accordance with their humidity requirements (Fig. 4). Xerophylous elements have eigenvalues around 0 . Conversely, hygrophilous elements have eigenvalues above 0.8 , so Axis 1 must represent the humidity gradient. Along Axis 2, taxa are separated according to their habitat preferences. Grassland elements have eigenvalues close to 0 . Forest steppe elements have eigenvalues above 0.5 . Along Axis 1 , the soil blocks are markedly separated from those of the Körös pit (Fig. 4). The former has negative, while the latter has positive eigenvalues, implying that relatively humid conditions must have prevailed during the life of the Körös culture in the area most likely attributable to the higher temperatures yielding higher evaporation. Along Axis 2, the lowermost three Körös blocks (F2S914 to F2S1116) have eigenvalues close to 0 similarly to the uppermost soil blocks (Fig. 4). The directly overlying Körös blocks however are characterized by positively shifted eigenvalues along Axis 1 marking a transformation in terrestrial habitats around the pit to a more closed stage (high grass), probably attributable to higher humidity values (Fig. 5). All in all, the observed transformation in the riparian environment triggered a similar adaptational feedback in the terrestrial vegetation as seen in the strong statistically significant correlation between the gained proxies of water velocity and humidity (Spearman $\left.r h o=0,833^{*} *^{3}\right)$. The pattern seen for the soil

\footnotetext{
$3 * *$ statistically significant correlation $(p=0.01)$
} 

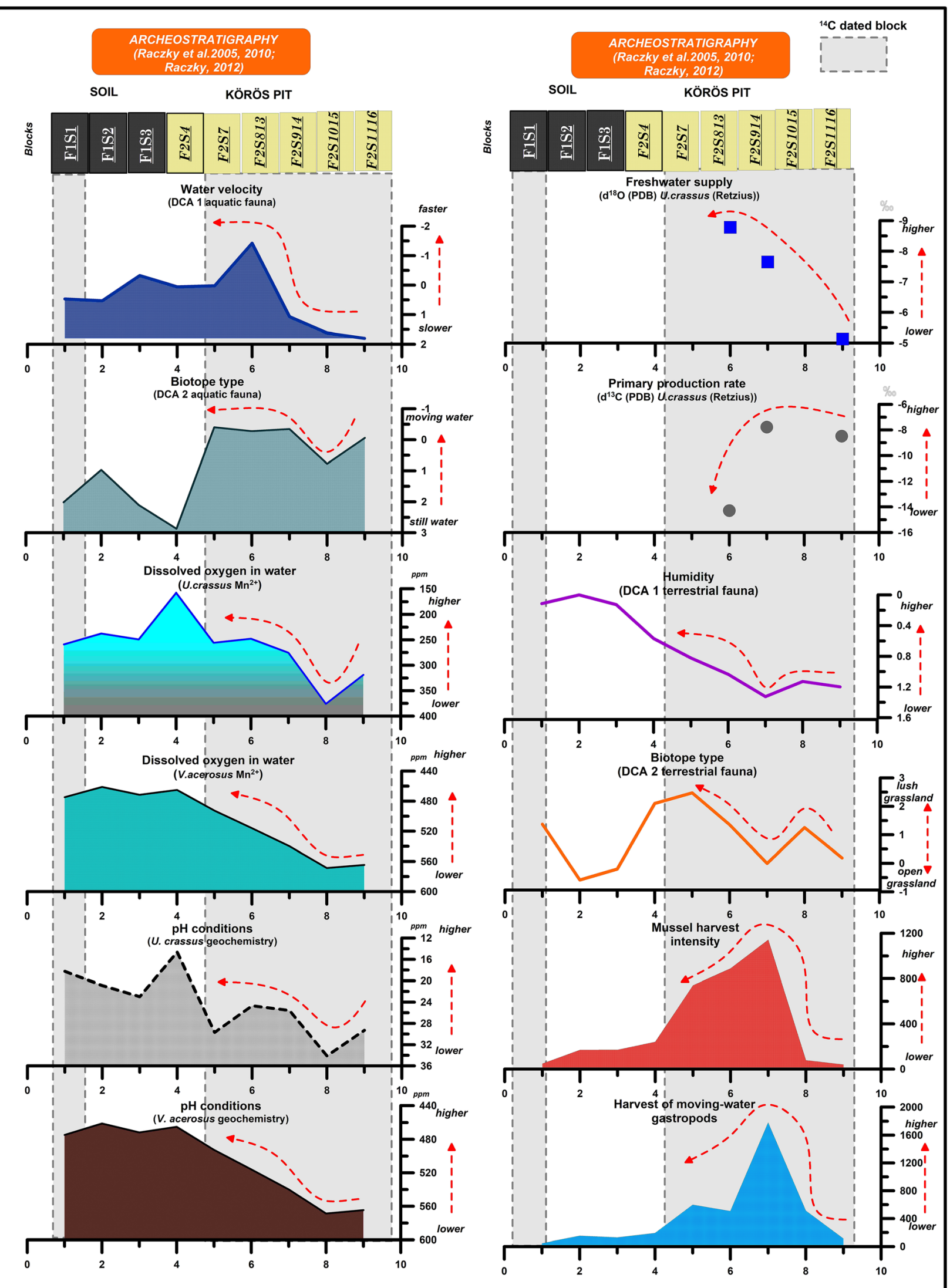

Fig. 5 Proxy values describing major environmental parameters and foraging strategy employed at the study site 
blocks is just the opposite of the Körös blocks implying a cessation of periods with higher humidity (Fig. 5).

\section{Geochemical properties of the studied freshwater fauna}

Concentrations of $\mathrm{Mn}^{2+}$ and $\mathrm{Fe}^{2+}$ in the shell ranged on the scale of some hundred ppms, while that of $\mathrm{Zn}^{2+}$ on the scale of tens. Samples are clearly separated from each other based on the average concentrations of all studied elements for both the rheophylic mussel and river snail taxa (Fig. 6). The pattern seen seems to be congruent with that observed for the taxonomic composition of the fauna, corroborating the assumption that compositional changes inferred are the outcome of the same transformations of the riparian environment despite the artificial nature of the deposit. The uppermost blocks of both the Körös pit and the soil (numbers 1-6 on Fig. 6) are unambiguously separated from the lowermost two blocks of the Körös pit (numbers 8 and 9) on all axes.

The highest concentration of manganese was recorded in the lowermost two blocks with values around 320-370 ppm for mussel shells and 90-100 ppm for gastropods. In general, the concentration of manganese is significantly lower in the overlying Körös pit blocks with a gradually decreasing trend.
A similar pattern was observed for iron and zinc as well in case of both taxa with minor discrepancies as seen by the strong correlation value (Spearman rho $=0.686$ ). It is interesting to note here that the recorded concentrations of all elements in the shells of the uppermost 4 Körös pit blocks were similar to those recorded for the modern taxon from River Tisza and European rivers and lakes (Bába et al. 2002; Ravera et al. 2003, 2007). On the basis of the concentration of manganese observed during the initial phase of site evolution corresponding to the lowermost two blocks, aquatic habitats were characterized by low dissolved oxygen levels most likely attributed to higher bioproduction rates. Higher bioproduction resulting in increased reduction of iron and manganese generally yields lower $\mathrm{pH}$ values (Richardson et al. 1988). A shift to lower values in all elements in the overlying blocks hallmarks an increase in dissolved oxygen of the waterbody and a shift in $\mathrm{pH}$ to higher values most likely as a result of decreased bioproduction. Furthermore, the general upward decrease in the concentration of all elements according to Lee and Wilson (1969) and Hill (1975) is a marker of larger discharge to the area (Fig. 5). These conditions can only develop in a floodplain setting as ours via more intensive floods carrying waters rich in oxygen and relatively deprived of dissolved elements.

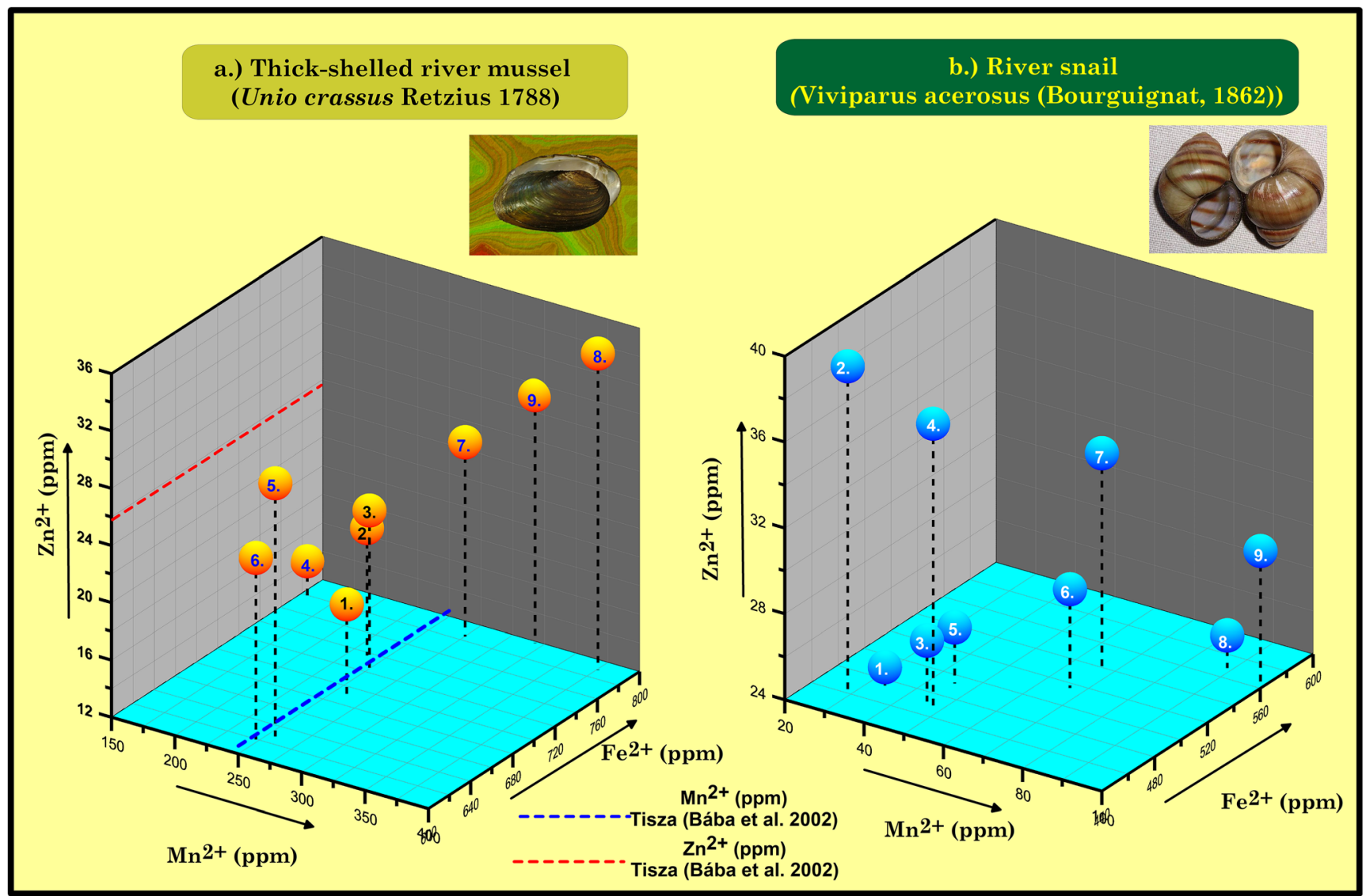

Fig. 6 The geochemical composition of the studied rheophylic mussel and river snail shells (numbers mark the vertical position of the blocks studied, arrows point to higher values in concentrations) 


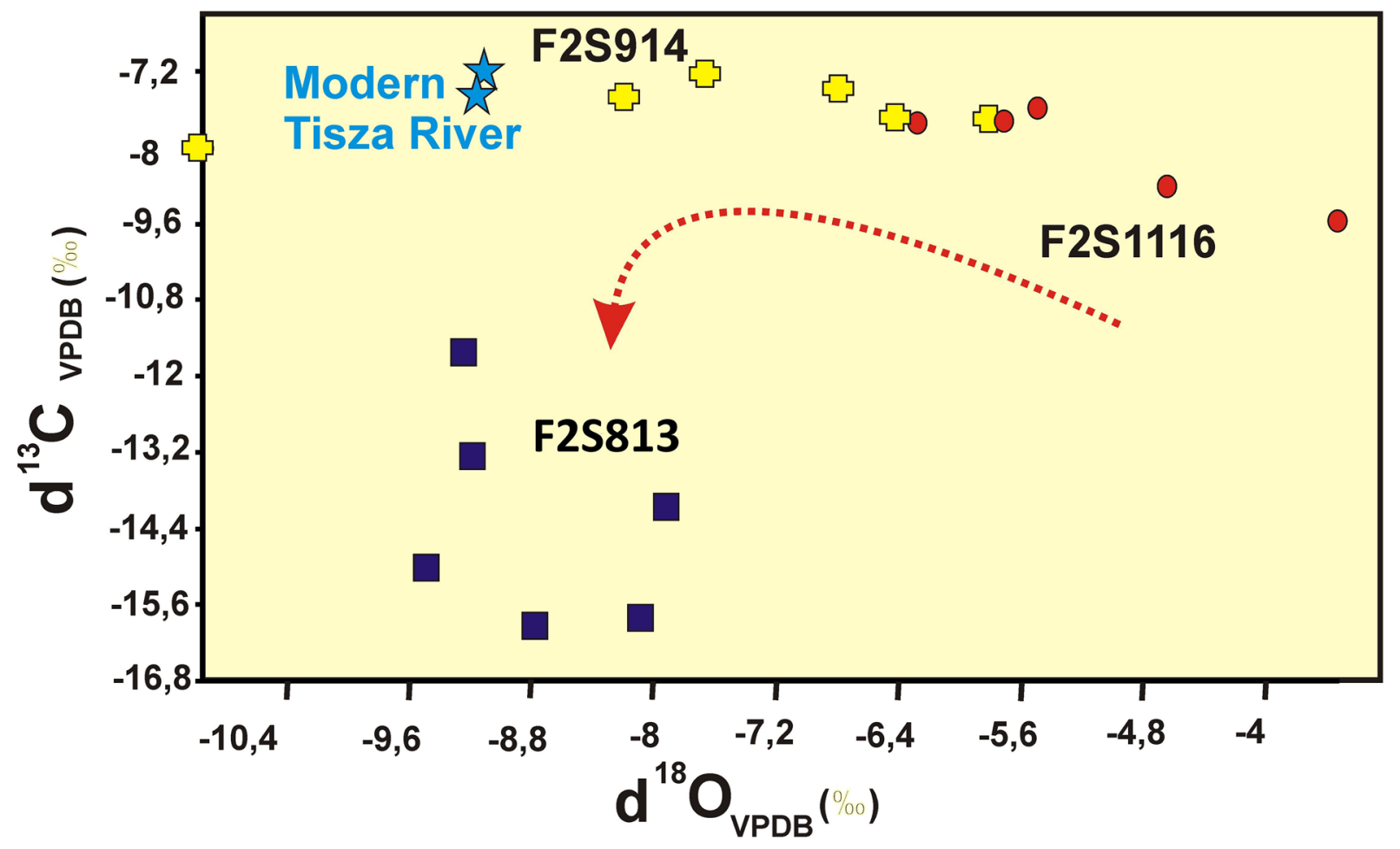

Fig. 7 The isotopic composition of thick-shelled river mussel from selected Körös pit blocks

A very similar pattern was observed for isotopes of mussel shells as well (Figs. 5 and 7). Samples of the lowermost block have higher values of $\delta^{13} \mathrm{C}_{\text {shell }}$ and $\delta^{18} \mathrm{O}_{\text {shell. }}$ Parallel with the observed decrease in the recorded trace elements, a negative excursion of both isotope values is observed in accordance with the literature (Caroll and Romanek 2008). Initially, this excursion is seen in $\delta^{18} \mathrm{O}_{\text {shell }}$ alone, while $\delta^{13} \mathrm{C}_{\text {shell }}$ remains relatively the same (F2S914). Finally, a major negative shift occurs in these values as well (F2S813). In a floodplain setting with standing waters, higher $\delta^{13} \mathrm{C}$ and $\delta^{18} \mathrm{O}$ values of shell carbonates may reflect drier conditions characterized by higher temperature values and more intense primary production (Caroll et al. 2006; Ellis et al. 2004; Peacock and Seltzer 2008). Higher temperatures enhance evaporation yielding positive $\delta^{18} \mathrm{O}_{\mathrm{TDIC}}$ water and $\delta^{18} \mathrm{O}_{\mathrm{TDIC}}$ shell values ${ }^{4}$ (Bowen 1991; Kennett and Voorhies 1995; Tripati et al. 2001; Davies and Muehlenbachs 2001; Dettman et al. 1999; Versteegh 2008). Aquatic plants and phytoplanktons tend to use the lighter isotope of carbon $\left({ }^{12} \mathrm{C}\right)$ in their metabolism due to energy reasons. This yields an increase in the $\delta^{13} \mathrm{C}_{\mathrm{TDIC}}$ water value (Hollander and Smith 2001; Leng and Marshall 2004). In the Swiss Lake Greifen, $\delta{ }^{13} \mathrm{C}_{\mathrm{TDIC}}$ values of near surface waters recorded during phytoplankton blooms were around 7.5\%o (McKenzie 1985; McKenzie and Hollander 1993),

\footnotetext{
${ }^{4}$ TDIC, total dissolved inorganic carbon
}

which is roughly the same as the average values of $\delta^{13} \mathrm{C}$ shell in samples of the lowermost block (F2S116) and that of the successive block F2S914.

This may indicate a similarity in environmental conditions, i.e., higher primary production rates. The initial negative shift of $\delta^{18} \mathrm{O}_{\text {shell }}$ may refer to the development of a cooler climate enjoying more precipitation (Caroll et al. 2006; Gustafson et al. 2007; Dettman et al. 1999). Mean July paleotemperatures received via the analysis of the terrestrial mollusk fauna however speak about a climate with warm conditions near our study site $\left(\sim 22^{\circ} \mathrm{C}\right)$ (Sümegi 2003a, 2003b, 2004, 2007), so rather this shift may indicate infiltration of waters into the study area with altered isotopic composition due to immense rainfall onto the watershed area of the Tisza River. Similar negative isotopic shifts were recorded in the lower reaches of the Rhein in relation to spring meltdown in the Alps (Ricken et al. 2003). The delayed negative excursion of $\delta^{13} \mathrm{C}_{\text {shell }}$ values with unchanged $\delta^{18} \mathrm{O}_{\text {shell }}$ values in case of the block F2S813 must be attributed to a delayed response in bioproduction rates to altered dissolved oxygen levels yielding a transformation of the trophic state as well (Leng and Marshall 2004). It is interesting to note though that $\delta^{13} \mathrm{C}_{\text {(TDIC) }}$ values recorded for groundwater and fluvial systems of Northern and Western Europe (bw.-10 and - 15\%o), which are also under the influence of the same cyclonic system carrying precipitation to our study area as well, are very 
similar to the ones recorded in our uppermost studied Körös block of F2S813 (Leng and Marshall 2004; Andrews et al. 1993, 1997).

To sum up the observed trajectory of geochemical transformations recorded in our shells are congruent with those inferred for the riparian environment via the analysis of taxonomic composition of the freshwater fauna. For the period corresponding to the lowermost blocks, an aquatic habitat of low dissolved oxygen levels, lower stable $\mathrm{pH}$ values, and higher bioproduction rates could be postulated. These were exchanged by conditions of high dissolved oxygen levels of the water, higher $\mathrm{pH}$ values, and lower bioproduction rates as well as negatively shifted $\delta^{18} \mathrm{O}$ values indicating the transport of waters of different isotopic composition to the floodplain, i.e., a clear outcome of more pronounced floods.

\section{Foraging and subsistence strategies inferred}

There is little information available on the importance of crop cultivation. Appearance of cereal phytoliths in the upper blocks of Feature 2 is the only data we have (Sümegi et al. 2012) but information on temporal changes of the importance of crop cultivation is not available. Detailed archeozoological studies highlighted the importance of second-line resources in subsistence besides domesticates (Bartosiewicz 2005, 2006, 2007; Pike-Tay et al. 2004; Raczky 2012; Raczky et al. 2010). It must be noted that the data presented is a sum of the entire feature hampering the elucidation of any temporal patterning. Nevertheless, the general composition of the vertebrate fauna of the archeozoological material speaks about a subdominance of the wild component (14.4\%) (Fig. 8) compared with domesticates $(85.6 \%)$ prevailed by caprines $(66.7 \%)$. It is interesting to note that ca. two-thirds of the wild component is given by freshwater vertebrates (Fig. 8). Within this component, wildfowl is the dominant along with freshwater fish. The versatility of the ifreshwater fish taxa and other aquatic vertebrates clearly speaks about a larger reliance on freshwater habitats for food by the Körös farmers in line with the expected resilience models.

Our shellfish material enabled us to tackle temporal changes in the use of freshwater resources as well. Exploitation of freshwater resources (river mussels and river snails) was generally low in the lowermost two Körös pit blocks (F2S1015 \& F2S1116) implying a negligible use of second-line resources during this period most likely as a result of abundance of other subsistence resources (Figs.5 and 8). Similarly, low harvest intensity values characterized the soil blocks. Peak exploitation of several hundred specimens was recorded for the contemporary Körös blocks (F2S813-F2S914) directly overlying the two lowermost blocks. The intensive use of second-line resources here is congruent with the inferred transformation of the nearby riparian environment due to the emergence of immense floods as seen in the strong correlation of our stream velocity proxy and harvest intensity values (Spearman rho $=$ $-0.680 *^{5} p=0.05$ ), which is a clear sign of social and economic stress in site development (Jones 2004). The reason for the negative correlation is that the negative shift in DCA1 values expressing an increase in stream velocity was followed by an increase in harvest intensity.

\section{Discussion}

The Körös site Nagykörü-Orchard is outstanding from the point of understanding the potential background causes of a major cultural transformation which occurred in the heart of the Carpathian Basin along the northern distribution line of first farming groups during the middle of the 6th millennium BC. It is the only site so far where subsistence strategies of the first farming groups arriving in the Carpathian Basin could have been studied in details at a longer temporal scale from their first settlement to about the stage of their cultural transformation. Collective evaluation of findings from this site and a comparison with other nearby contemporary sites of Tiszapüspöki-Karancspart-Háromága (Sümegi 2003b, 2004; Gulyás and Sümegi 2004, 2012a) and Ecsegfalva 23 (Whittle 2007) ${ }^{6}$ located along the referred borderline as well enables us to capture and model the characteristics of aquatic and terrestrial habitats of the alluvial plain well before and right around this transformation event on a regional scale. It must be noted though that the other two contemporary sites of Tiszapüspöki-Karancspart-Háromága and Ecsegfalva 23 provide only a general view of the hydrological and environmental conditions at the time of their existence without insight into any smaller-scale temporal trend.

Based on our findings, the first phase of site evolution corresponding to the opening of the 6th millennium BC was characterized by relatively calm and balanced conditions on the floodplain hydraulically speaking (Fig. 9a). However, a pronounced transformation was documented in both the freshwater and terrestrial habitats in the period corresponding to the uppermost blocks of the site of Nagykörü $(\sim 5750-$ 5700 cal BC). This period is directly preceding the time of cultural transformation dated around 5620 cal BC (Fig. 3) (Domboróczki 2010). Furthermore, it is also contemporary with a well-documented nearby site of Ecsegfalva 23 as well (5750-5650 cal BC) (Fig. 3) (Whittle 2007; Sümegi 2007; Gulyás et al. 2007).

The initial still-water conditions characterized by lower dissolved oxygen levels of the waterbody and an elevated primary production on the floodplain (Fig. 9a) were exchanged for stream water conditions (Fig. 9b). This was accompanied by a significant increase in the water's dissolved

\footnotetext{
5 *statistically significant correlation at $p=0.05$.

6 for location of these see Fig.1.
} 


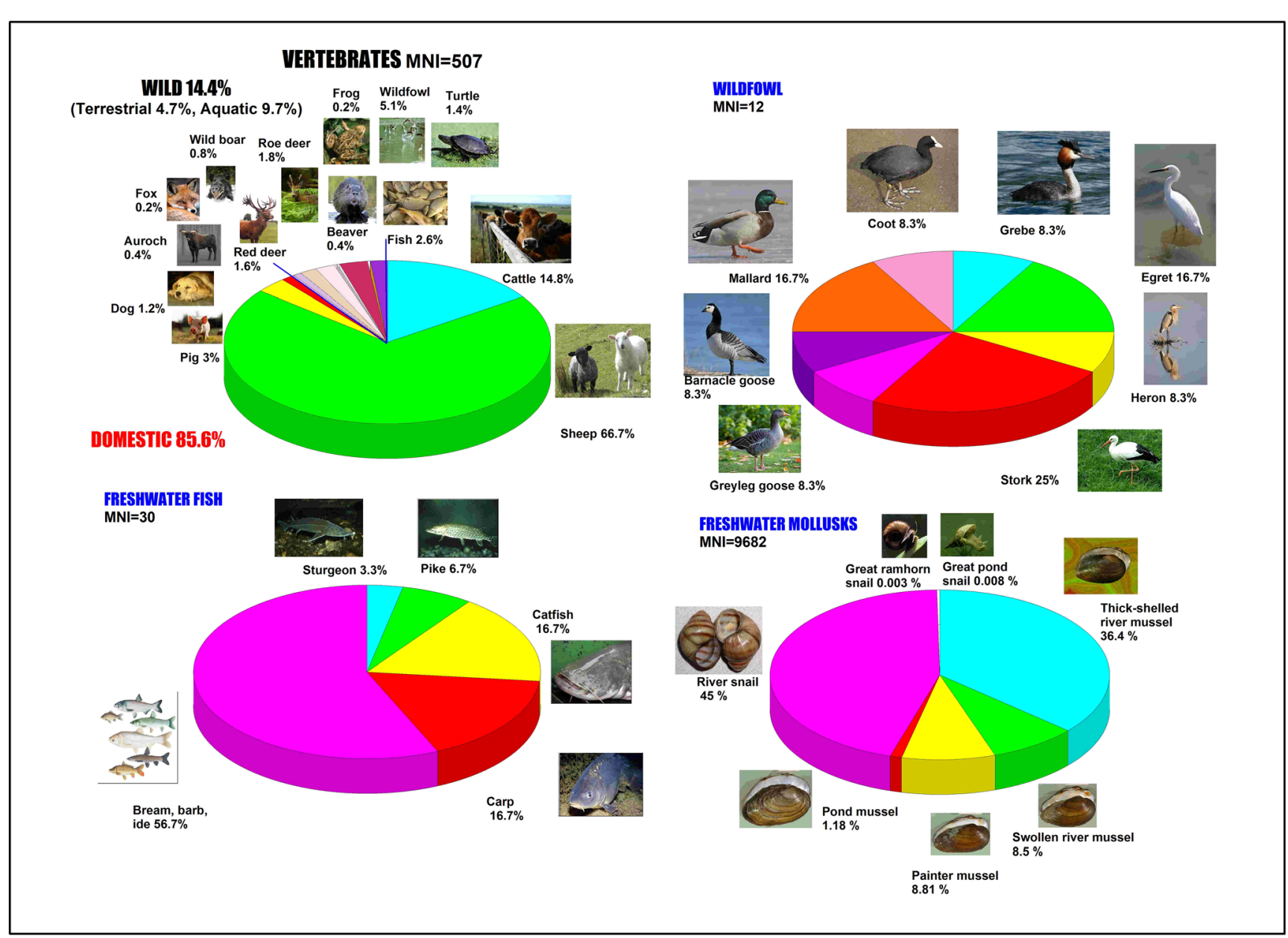

Fig. 8 The composition of archeofaunal remains from the site of Nagykörü-Orchard (after Bartosiewicz 2005, 2006, 2007; Raczky et al. 2010 and this study)

oxygen content and a shift in $\mathrm{pH}$ marking the influences of heightened flood activities. These changes also brought about a sudden drop in the rate of primary production within the isolated pools of the floodplain. The inferred transformations on the floodplain were equally observable in the adjacent elevated terrestrial areas as well. As a result of the more pronounced floods, the majority of the generally dry near-bank and wet meadow areas must have been inundated and remained under higher water for the major part of the year. Furthermore, the relatively constant inundation must have significantly raised the level of subsurface water table yielding so-called inland water outburst in the vicinity of the test pit and the major part of the flood-free lag surface of Nagykörü (Fig. 9b).

These changes must have further reduced the areas potentially available for grazing or plant cultivation. The strong negative excursion in the $\delta^{18} \mathrm{O}$ of freshwater shells (Figs. 5 and 7) indicates a continuous supply of freshwater of different isotopic composition onto the floodplain, marking the development of long-lasting pronounced iterative flood cycles for the referred transformation period. Higher temperatures of the growth season must have favored elevated evapotranspiration seen in higher humidity values.

Findings of a similar study for the site of Ecsegfalva 23 (Fig. 2), corresponding to the transformational phase of the culture's evolution, also point to the prevalence of movingwater conditions on the floodplain during the referred period seen in the taxonomic composition of shellfish foraged (Gulyás et al. 2007) and the geochemistry of freshwater shells, yielding relatively high dissolved oxygen levels of the waterbody and slightly fluctuating pH values (Gulyás 2011). All these factors point to the effects of immense, iterative floods for the period of the settlement resulting in the reduction of potentially available landscape resources of horticulture, and animal husbandry in concert with other paleoecological results from the site. The relatively high abundance of ash pollen grains, a species tolerating constant inundation, from about $6000 \mathrm{cal} \mathrm{BC}$ onwards in the profile of the meander of the adjacent Kiri-tó, is another independent marker of pronounced floods to the area between 5750 and 5650 cal BC years (Willis 2007). The dominance of aquatic plants in both the macrobotanical and pollen material also 


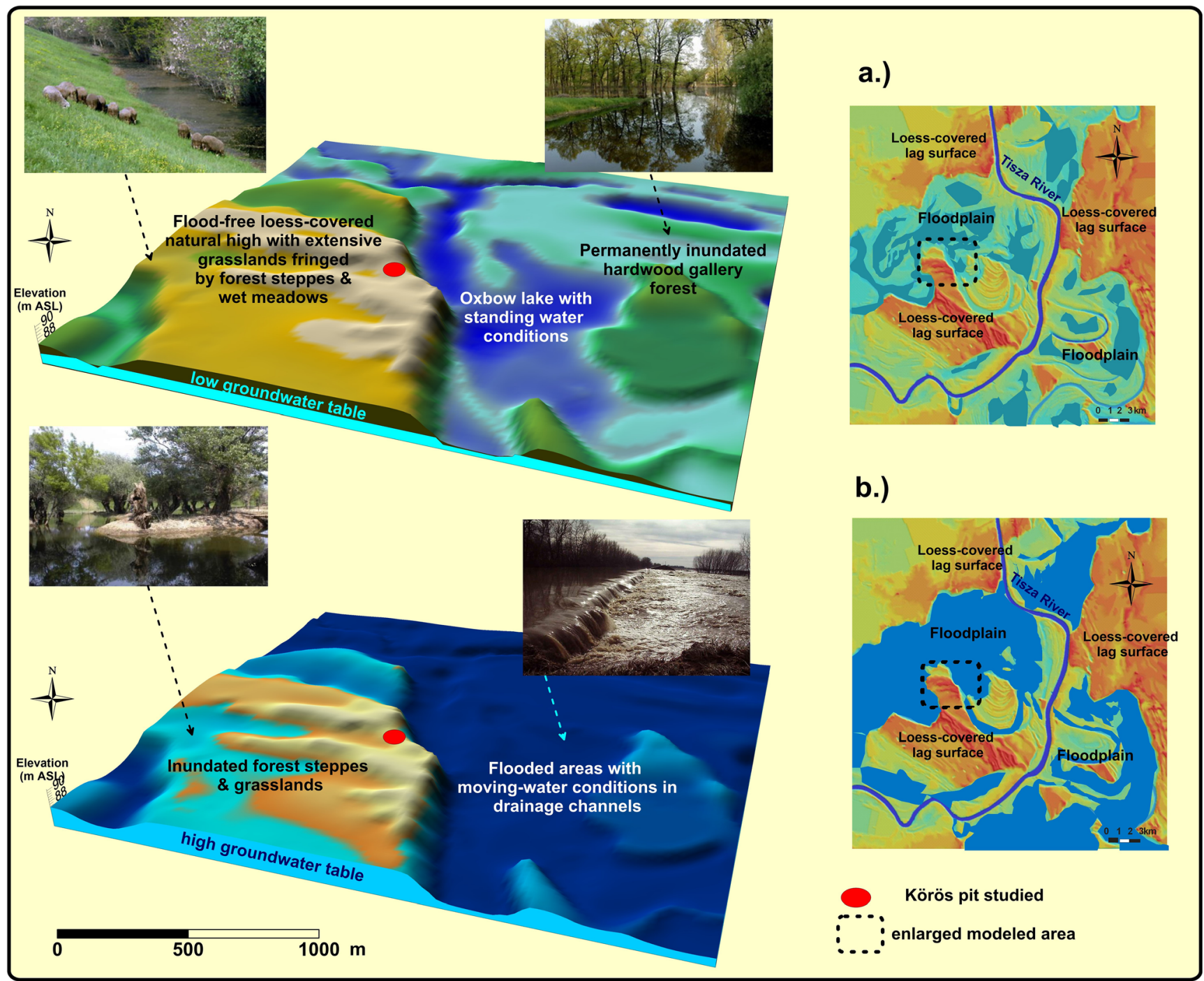

Fig. 9 Inferred environmental conditions of the Körös site of Nagykörü between 5960 and 5690 cal BC years

indicates constant inundation in the vicinity of the site of Ecsegfalva (Willis 2007). Phytolith analysis of soil samples from the site also corroborated the vision of an inundated floodplain with higher water levels. The material was dominated by aquatic plants. Conversely, reed intolerant of high water levels is completely missing (Windland 2007). Detailed isotopic analysis of human and animal bones with relatively high $N$ and low $C$ values further corroborates this paleogeographic reconstruction (Pearson and Hedges 2007). The observed shift in the isotopic values was attributed to arthritic stress caused by floodwaters on the one hand, or the sideeffects of grazing on inundated, artificially manured arable lands (Sebilo et al. 2003; Pearson and Hedges 2007). High $N$ values in human bones on the other hand may refer to intensified reliance on aquatic food sources just like in the case of the site of Lepenski Vir (Cook et al. 2001; Bonsall et al. 2004). All in all, we may infer the development of iterative, high level, pronounced floods for the period corresponding to the cultural transformation of first farming groups in this site as well similarly to our study site of Nagykörü. A common local response to this environmental stress was the development of flexible opportunistic agricultural regimes observable in our study site of Nagykörü as well (Raczky et al. 2010). This included an increased reliance on multiple resources like freshwater fish, wildfowl (Bartosiewicz 2007; Gál 2007; Bartosiewicz and Gál 2007; Raczky et al. 2010), and shellfish (Gulyás et al. 2007) on the one hand (Fig. 8). Plus, there was the introduction of smallplot horticultural production on the other hand (Sümegi 2004; Sümegi et al. 2005; Whittle 2007).

The other nearby site of Tiszapüspöki, with only archeostratigraphy-based absolute chronology (Fig. 2), was also characterized by prevailingly still-water floodplain conditions with intermittent periods of stream conditions also seen from archeomalacological data (Sümegi 2004; Gulyás and Sümegi 2004). Knowing the geographical and 


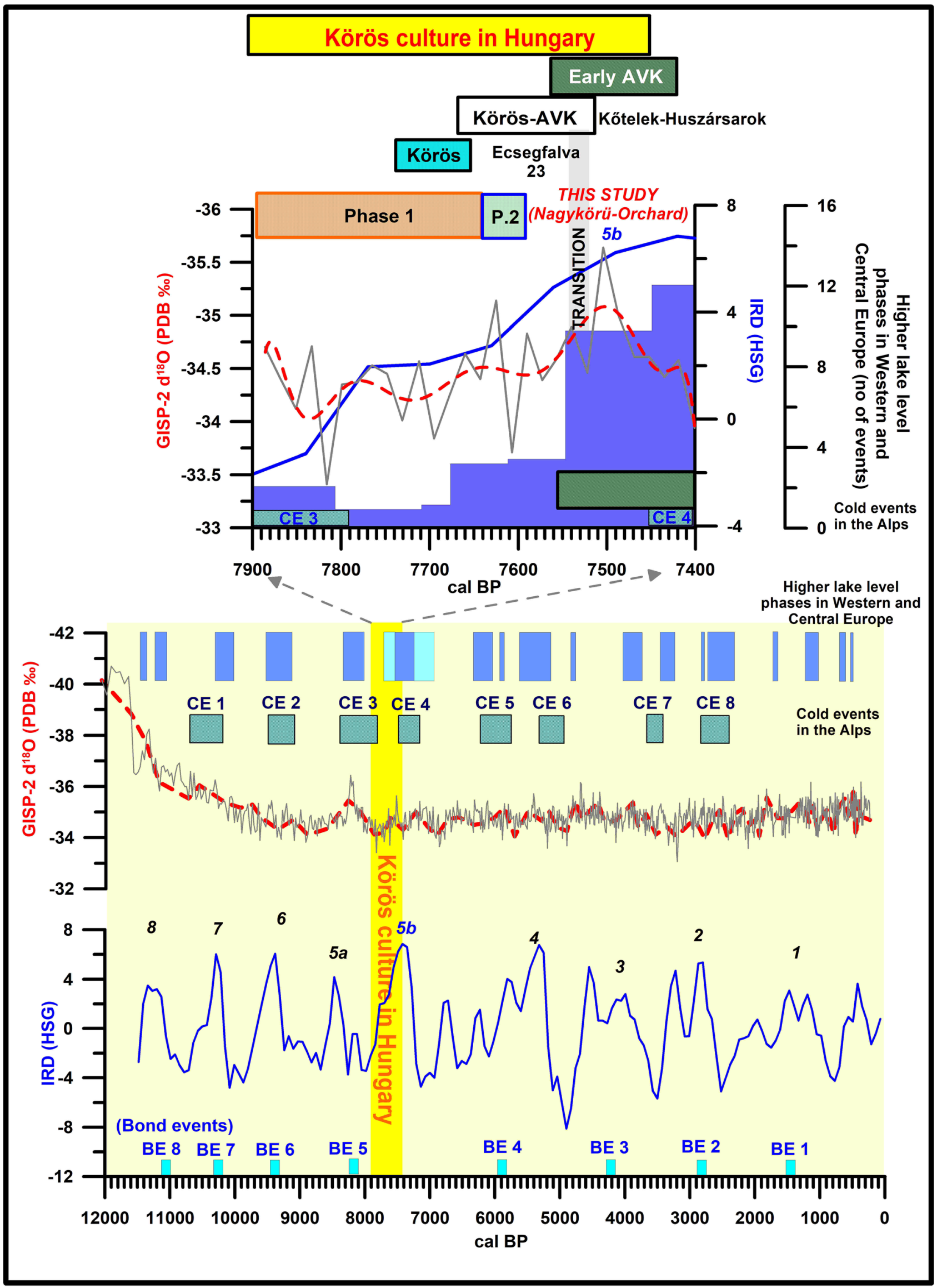


Fig. 10 Selected paleoclimatic proxies hallmarking the IRD 5b climatic event within the stratigraphic framework of our study

data source: (IRD-concentration of ice-rafted debris in the Northern Atlantic (Bond et al. 2001), GISP-2 $\delta^{18} \mathrm{O}$ (Grootes et al. 1993), Alpine cold events (Haas et al. 1998), Lake levels in Western Central Europe (Magny et al. 2003; Magny 2004))

geomorphological endowments of the site located at a larger distance from the active channel of the river Tisza on the floodplain, these could have developed during periods of higher floods alone. The inferred $\mathrm{pH}$ conditions and dissolved oxygen content of the studied waterbody shown from geochemistry of freshwater shells seem to have corroborated this assumption, yielding value characteristic of fluvial systems (Gulyás 2011). Reduced growth rate of the dominant stillwater shellfish also refers to the presence of some constant environmental stress, probably attributable to increased current conditions in the drainage channel of the floodplain, hosting the original fauna (Gulyás and Sümegi 2004). Although the site of the settlement remained flood-free as shown by the findings of detailed geoarcheologial investigations, the general distribution of marshy loess and overlying hydromorphic soils also indicate high, but somewhat lower inundation of the floodplain compared to the other two sites (Sümegi 2004). This must be attributed to the more distant ( $7-8 \mathrm{~km}$ ) and protected position of the site on the floodplain regarding from the active riverbed of the Tisza, yet the constancy of these moderated flood events is clearly expressed in the mentioned growth parameters and geochemistry of the harvested freshwater shellfish fauna.

Based on our findings presented above, the development of a mental crisis in the representatives of the Körös groups along their northern marginal distribution in the Carpathian Basin postulated by Raczky et al. (2010) cannot be attributed to the hostility of a new, unknown environment forcing new adaptations alone, but rather as our data shows, these factors must have been complemented and further amplified by a major climatic anomaly connected to IRD event $5 \mathrm{~b}$ initiating around 5.7 ky BC (Spurk et al. 2002; Strien and Gronenborn 2005; Benito et al. 2015) (Fig. 10). This event is recorded in an increased southward transport of ice-rafted debris in the Northern Atlantic marking the southward extension of cooler ocean waters. An intensive cyclonic activity and cooler temperatures over Western Europe generally connected to IRD (Ice Rafted Debris) peaks (Bond et al. 1997, 2001) in the Atlantic region led to higher flood activities in temperate Europe and the Mediterranean as well (Benito et al. 2015). In Hungary, higher continentality provided by the basin setting preserved warmer conditions. Nevertheless, increased rainfall onto the watershed of major rivers including the Tisza River crossing the GHP triggered heightened floods.

Signs of intensified flooding were noted recently in NW Hungary for this period as well (Törőcsik et al. 2019). Higher and more pronounced floods must have emerged in the watershed of the Tisza River. These hydrological changes isolated neighboring Körös culture groups and reduced the areas of pasturelands and potentially available agricultural plots, social space on the floodplain. Negative effects must have been more pronounced closer to the active river channel (Nagykörü), but somewhat moderated in the more distant floodplain areas (Ecsegfalva, Tiszapüspöki). These conditions must have been utterly unfavorable to a rather conservative Mediterranean type of economy based on goat and sheep like the Körös culture creating a real crisis situation. The immense appearance of these negative events must have triggered a rapid adaptational process first seen in the wider use of second-line resources, mainly freshwater ones. Then, finally leading to the transformation of subsistence and settlement strategies seen in the displacement of settlements to higher areas (Sümegi 2003b), as well as the material culture (Raczky 1983; Raczky et al. 2010; Bánffy 2004a, 2004b, 2006; Oross and Bánnfy 2009; Domboróczki 2010; Raczky 2012).

\section{Concluding remarks}

Historical communities often choose floodplain areas for settlement despite the risk of seasonal flooding because of numerous advantages, as these complex habitats with a diverse natural flora and fauna as well as soils provide multiple sources of subsistence and permanent water supply (Gardner 2005; Gillings 2007; Raczky et al. 2010). The unknown distribution of resources, variable flooding intensities due to climate changes pose significant challenges to communities to which they are forced to adapt. The success of adaptation is dependent on the resilience of the given group. Körös Culture pastoralists responded to these challenges by complementing their diet with opportunistically exploited wild resources, dominantly freshwater ones (Bartosiewicz 2005, 2006, 2007; Pike-Tay et al. 2004; Raczky 2012; Raczky et al. 2010, this study). Archeomalacological investigations presented here is a useful and suitable tool for capturing temporal changes in flood intensities and tackling subsistence changes through time enabling us to understand reasons behind subsistence and cultural changes (Gulyás 2011; Gulyás and Sümegi 2011a, 2011b, 2012a, 2012b). Based on our new results and a regional comparison with other coeval paleohydrological, paleoecological, and archeological records, climate-induced dynamic temporal changes in the hydrology of the originally hostile environment must have been a more important push factor in adaptation of the first farmers than simply the static new natural endowments which were less suitable for engagement of a Mediterranean type agriculture. Similar climate-induced hydrological changes and adaptations by farming communities have been documented for Late Neolithic cultures of the GHP as well (Gulyás 2011; 
Gulyás and Sümegi 2011a, 2011b, 2012a, 2012b). Extension of our work and methodology in the future to other areas of the Carpathian Basin such as Körös and Starcevo sites found in Transdanubia and along the Danube River can help us to see if these dynamic changes also affected the landscape, hydrology, and the social and economic lives of the mentioned early farming groups.

Acknowledgments The authors would like to express their gratitude to all colleagues working at the Department of Geology and Paleontology, University of Szeged for assisting in the technical part of paper preparation. Special thanks to Pál Raczky and Alexandra Anders at the ELTE Univeristy of Budapest for granting access to the material subjected to analysis as well as the archeostratigraphy. Research has been carried out within the framework of University of Szeged, Interdisciplinary Excellence Centre, Institute of Geography and Earth Sciences, Long Environmental Changes Research Team. Finally, thanks are due to the editorial board and the two reviewers whose comments made the final version of this paper stronger and clearer than early drafts.

Funding information Open access funding provided by University of Szeged. This study is funded by the Ministry of Human Capacities, Hungary grant 20391-3/2018/FEKUSTRAT and GINOP-2.3.2-152016-00009 "ICER."

Open Access This article is licensed under a Creative Commons Attribution 4.0 International License, which permits use, sharing, adaptation, distribution and reproduction in any medium or format, as long as you give appropriate credit to the original author(s) and the source, provide a link to the Creative Commons licence, and indicate if changes were made. The images or other third party material in this article are included in the article's Creative Commons licence, unless indicated otherwise in a credit line to the material. If material is not included in the article's Creative Commons licence and your intended use is not permitted by statutory regulation or exceeds the permitted use, you will need to obtain permission directly from the copyright holder. To view a copy of this licence, visit http://creativecommons.org/licenses/by/4.0/.

\section{References}

Andrews JE, Riding R, Dennis PF (1993) Stable isotope compositions of recent freshwater cyanobacterial carbonates from the British Isles: local and regional environmental controls. Sedimentology 40:303314

Andrews JE, Riding R, Dennis PF (1997) The stable isotopic record of environmental and climatic signals in modern terrestrial microbial carbonates from Europe. Paleogeogr Paleoclimatol Paleoecol 129: 171-189

Anthony DW (1990) Migration in archeology: the baby and the bathwater. Am Anthropol 92:985-914

Bába K, Sári D, Tóth T (2002) Kagylócönózisok különböző aljzaton, a 2000. évi nehézfém szennyezés. (Mussel assemblages on differing substrates. The 2000 cyanide pollution). SOOSIANA 30:37-48

Bánffy E (2000) The late Starčevo and the earliest linear pottery groups in Western Transdanubia. Documenta Praehistorica 27:173-185

Bánffy E (2004a) The 6th millennium BC boundary in Western Transdanubia and its role in the central European transition (the Szentgyörgyvölgy-Pityerdomb settlement). Varia Archaeologica Hungarica 15:1-451

Bánffy E (2004b) Neolithic contatcs: adaptation, exchange of information (an introduction). Antaeus 27:11-16
Bánffy E (2006) Eastern, central and Western Hungary-variations of Neolithisation models. Documenta Praehistorica 33:133-135

Bánffy, E., Oross, K. 2010, The earliest and early phase of the LBK in Transdanubia, in: the spread of the Neolithic to Central Europe, International Symposium, Mainz 24 June - 26 June 2005, Gronenborn D., Petrasch J. (eds), RGZM - TAGUNGEN, Band 4, Verlag des RGZM, Mainz, pp. 147-175.

Bartosiewicz L (2005) Plain talk: animals, environment and culture in the Neolithic of the Carpathian Basin and adjacent areas. In: Bailey DW, Whittle A, Cummings V (eds) Unsettling the Neolithic. Oxbow Books, Oxford, pp 51-63

Bartosiewicz L (2006) Régenvolt háziállatok. L’Harmattan Kiadó, Budapest

Bartosiewicz L (2007) Fish remains. In: Whittle A (ed) The early Neolithic on the great Hungarian plain- investigations of the Körös culture site of Ecsegfalva 23, Békés County. HAS Institute of Archeology, Budapest, pp 377-394

Bartosiewicz L, Gál E (2007) Sample size and taxonomic richness in mammalian and avian bone assemblages from archeological sites. Archeometriai Mühely 2007(1):37-44

Bauer G, Wachtler K (2001) Ecology and evolution of the freshwater mussels Unionidae, ecological studies. Berlin: Springer

Behrensmeyer AK (1991) Terrestrial vertebrate accumulation. In: Allison PA, Briggs DEG (eds) Taphonomy, releasing the data locked in the fossil record. Plenum, New York

Behrensmeyer AK, Hill AP (eds.) (1980) Fossils in the making: vertebrate taphonomy and paleoecology. Chicago: University of Chicago Press

Behrensmeyer AK, Kidwell SM, Gastaldo MA (2000) Taphonomy and paleobiology. Paleobiology 26:103-144

Benito G, Macklin MG, Panin A, Rossato S, Fontana A, Jones AF, Machado MJ, Matlakhova E, Mozzi P, Zielhofer C (2015) Recurring flood distribution patterns related to short-term Holocene climatic variability, nature. Sci Rep 5(16398):1-8

Berger JF, Guilaine J (2009) The 8200 cal BP abrupt environmental change and the Neolithic transition: a Mediterranean perspective. Quat Int 200:31-49

Bond G, Showers W, Cheseby M, Lotti R, Almasi P, deMenocal P, Priore P, Cullen H, Hajdas I, Bonani G (1997) A pervasive millenial-scale cycle in the North Atlantic Holocene and glacial times. Science 278: $1257-1266$

Bond G, Kromer B, Beer J, Muscheler R, Evans MN, Showers W, Hoffmann S, Lotti-Bond R, Hajdas I, Bonani G (2001) Persistent solar influence on North Atlantic climate during the Holocene. Science 294:2130-2136

Bonsall C, Cook GT, Hedges REM, Higham TFG, Pickard C, Radovanovic I (2004) Radiocarbon and stable isotopic evidence of dietary change from the Mesolithic to the Middle Ages in the Iron Gates: new results from Lepenski Vir. Radiocarbon 46:293-300

Bowen R (1991) Isotopes and climates. Elsevier Scientific Publishers, New York

Bronk Ramsey C, Lee S (2013) Recent and planned developments of the program OxCal. Radiocarbon 55(2-3):720-730

Broughton JM (1999) Resource depression and intensification during the Late Holocene, San Francisco Bay. Berkeley: University of California Press

Burger J, Gronenborn D, Forster P, Matsumura S, Bramanti B, Haak W (2006) Response to comment on "ancient DNA from the first European farmers in 7500-year-old Neolithic sites". Science 312(5782): 1875

Butler VL, Campbell SK (2004) Resource intensification and resource depression in the Pacific northwest of North America: a zooarchaeological review. J World Prehist 18(4):327-405

Byers DA, Broughton JM (2004) Holocene environmental change, artiodactyl abundances, and human hunting strategies in the Great Basin. Am Antiq 69:251-271 
Caroll M, Romanek CS (2008) Shell layer variation in trace element concentration for the freshwater bivalve Elliptio complanata. GeoMar Lett 28:369-381

Caroll MC, Romanek C, Paddock L (2006) The relationship between the hydrogen and oxygene isotopes of freshwater bivalve shells and their home streams. Chem Geol 234:211-222

Carré M, Klaric L, Lavallée D, Julien M, Bentaleb I, Fontugne M, Kawka $\mathrm{O}$ (2009) Insights into early Holocene hunter-gatherer mobility on the Peruvian Southern Coast from mollusk gathering seasonality. J Archeol Sci 36:975-1005

Chatfield C, Collins AJ (1980) Introduction to multivariate analysis. Chapman and Hall, New York

Childe VG (1956) Piecing together the past. Routledge and Kegan Paul, London

Claasen C (1998) Shells. Cambridge University Press, Cambridge

Cook GT, Bonsall C, Hedges REM, McSweeney K, Boronean V, Pettit PB (2001) A freshwater diet-derived C-14 reservoir effect at the stone age sites in the Iron Gates gorge. Radiocarbon 43:453-460

Coombes P, Barber K (2005) Environmental determinism in Holocene research: casuality or coincidence? Area 37:303-311

Csányi M (2003) Nagykörü-marsi part. (the high bluff of Nagykörü). Régészeti kutatások Magyarországon 257:42-78

Davies P (1998) Numerical analysis of sub-fossil wet-ground molluscan taxocenes from overbank alluvium at Kingsmead Bridge, Wiltshire. J Archeol Sci 25:39-52

Davies LG, Muehlenbachs K (2001) A Late Pleistocene to Holocene record of precipitation reflected in Margaritifera falcata shell $\mathrm{d}^{18} \mathrm{O}$ from three archeological sites from the lower Salmon River canyon, Idaho. J Archeol Sci 28:291-303

Dettman DL, Reische AK, Lohmann KC (1999) Controls on the stable isotope composition of seasonal growth bands in aragonitic freshwater bivalves (Unionidae). Acta Geochimica et Cosmochimica 63: $1049-1057$

Digby PGN, Kempton RA (1987) Population and community biology series: multivariate analysis of ecological communities. Chapman and Hall, London

Domboróczki L. (2010) Neolithization in northeastern Hungary: old theories and new perspectives, in: the spread of the Neolithic to Central Europe, International Symposium, Mainz 24 June - 26 June 2005, Gronenborn D., Petrasch J. (eds), RGZM - TAGUNGEN, Band 4, Verlag des RGZM, Mainz, pp. 175-187

Domboróczki L., Raczky P. (2010) Excavations at Ibrány-Nagyerdő and the northernmost distribution of the Körös culture in Hungary, in: Neolithization of the Carpathian Basin: northernmost distribution of the Starčevo/Körös Culture, papers presented on the symposium organized by the EU project FEPRE, Kraków, Kozłowski JK, Raczky P (eds), Polish Academy Of Arts And Sciences : Institute of Archaeological Sciences of the Eötvös Loránd University, Kraków : Budapest, pp. 191-218

Domboróczky L (2003) Radiocarbon data from neolithic archaeological sites in Heves County (north-eastern Hungary). Agria 39:5-71

Domboróczky L (2005) A Körös - kultúra északi elterjedési határának problematikája a Tiszaszölös-Domaháza-Pusztán végzett ásatás eredményeinek fényében. (Problems around the northern distribution boundary of the Körös culture in the light of new results from Tiszaszölös-Domaháza-Puszta). Archeometriai Mühely 1:5-15

Drysdale R, Zanchetta G, Hellstrom J, Maas R, Fallick A, Pickett M, Cartwright I, Piccini L (2006) Late Holocene drought responsible for the collapse of Old World civilizations is recorded in an Italian cave flowstone. Geology 34:101-104

Ellis KG, Mullins HT, Patterson WP (2004) Deglacial to middle Holocene climate change in the northeastern United States inferred from multi-proxy stable isotope data, Seneca Lake, New York. J Paleolimnol 31:343-361

Erman DC, Erman NA (1984) The response of stream macroinvertebrates to substate size and heterogeneity. Hydrobiologia 108:75-82
Evans JG (1972) Landsnails in archeology. Seminar Press, London

Gál E (2007) Bird remains. In: Whittle A (ed) the early Neolithic on the great Hungarian plain- investigations of the Körös culture site of Ecsegfalva 23, Békés County. MTA Institute of Archeology, Budapest, pp 361-377

Gardner AR (2005) Natural environment or human impact? A palaeoeocological study of two contrasting sites in north-eastern Hungary. In: Gál E, Juhász I, Sümegi P (eds) Environmental archaeology in north-eastern Hungary. Archaeological Institute of the Hungarian Academy of Science, Budapest, pp 87-106

Gillings M (2007) The Ecsegfalva landscape: affordance and inhabitation. In: Whittle A (ed) the early Neolithic on the great Hungarian plain. Investigations of the Körös culture site of Ecsegfalva, 23, County Békés: Varia Archaeologica Hungarica, XXI. Publicationes Instituti Archaeologici Academia Scientiarum Hungaricae Budapestini, Budapest, pp 31-46

Gronenborn, D. (2019) Expansion of farming in western Eurasia

Grootes PM, Stuiver M, White JWC, Johnsen S, Jouzel J (1993) Comparison of oxygen isotope records from the GISP2 and GRIP Greenland ice cores. Nature 366:552-554

Gulyás S (2011) Az édesvízi kagylók szerepe a kárpát-medencei neolit közösségek gazdálkodásának és az ártéri, folyóvízi környezet lokális és regionális adottságainak rekonstrukciójában (Freshwater shellfish as archives in reconstructing subsistence strategies and local and regional endowments of the riparian environment of Neolithic communities in the Carpathian Basin). unpublished $\mathrm{PhD}$ thesis. Szeged: University of Szeged

Gulyás S, Sümegi P (2004) Some aspects of prehistoric shellfishing from the early Neolithic Körös site of Tiszapüspöki, Hungary: methods and findings. SOOSIANA Hungarian Malacological Newsletter Supplement 32:1-60

Gulyás S, Sümegi P (2011a) Riparian environment in shaping social and economic behaviour during the first phase of the evolution of late Neolithic tell complexes in SE Hungary (6th/5th millenia BC). J Archaeol Sci 38:2683-2695

Gulyás S, Sümegi P (2011b) Farming and/or foraging? New environmental data to the life and economic transformation of late Neolithic tell communities (Tisza Culture) in SE Hungary. J Archaeol Sci 38: 3323-3339

Gulyás S, Sümegi P (2012a) Reconstructing past hydrologies of river Tisza using multivariable paleoecological analysis. In: Geiger J, Pál-Molnár E, Malvic T (eds) New horizons in central European Geomathematics, Geostatistics and Geoinformatics. Geolitera Press, Szeged, pp 113-131

Gulyás S, Sümegi P (2012b) Édesvízi puhatestűek a környezetrégészetben. (Freshwater mollusks in environmental archeology). Geolitera Publishers, Szeged, p 250

Gulyás S, Tóth A, Sümegi P (2007) The zooarcheological analysis of freshwater bivalve shells and their relevance regarding the life of a Neolithic community. In: Whittle A (ed) The early Neolithic on the great Hungarian plain- investigations of the Körös culture site of Ecsegfalva 23, Békés County. MTA Institute of Archeology, Budapest, pp 395-413

Gulyás S, Sümegi P, Molnár M (2010) New radiocarbon dates from the late Neolithic tell settlement of Hódmezővásárhely-Gorzsa, SE Hungary. Radiocarbon 52:1458-1464

Gustafson L, Showers W, Kwak T, Levine J, Stoskopf M (2007) Temporary and spatial variability in stable isotope compositions of a freshwater mussel: implications for biological and ecological studies. Oecologia 152:140-150

Haas JN, Richoz I, Tinner W, Wick L (1998) Synchronous Holocene climatic oscillations recorded on the Swiss Plateau and at the timberline in the Alps. Holocene 8:301-309

Haldon J, Rosen A (2018) Society and environment in the East Mediterranean ca 300-1800 CE. Problems of resilience, adaptation and transformation. Human Ecol 46(3):275-290 
Hammer O, Harper DAT (2005) Paleontological data analysis. WileyBlackwell, New York

Hill F (1975) Effects of the environment on animal exploitation by archaic inhabitants of the Koster site, Illinois. Ph.D. dissertation, Biology, University of Louisville

Hill MO, Gauch HG Jr (1980) Detrended correspondence analysis: an improved ordination technique. Vegetatio 42:47-58

Hollander DJ, Smith MA (2001) Microbially mediated carbon cycling as a control on the $\mathrm{d}^{13} \mathrm{C}$ sedimentary carbon in eutrophic Lake Mendota (USA): new models for interpreting isotopic excursions in the sedimentary record. Acta Geochimica et Cosmochimica 65: 4321-4337

Jakucs J, Bánffy E, Oross K, Voicsek V, Bronk Ramsey C, Dunbar E, Kromer B, Bayliss A, Hofmann D, Marshall P, Whittle A (2016) Between the Vinča and Linearbandkeramik worlds: the diversity of practices and identities in the 54th-53rd centuries cal BC in Southwest Hungary and beyond. J World Prehis 29:267-336. https://doi.org/10.1007/s10963-016-9096-x

Jones EL (2004) Dietary evenness, prey choice and human environment interactions. J Archeol Sci 31:307-317

Kalicz N (1970) Agyag istenek. A neolitikum és a rézkor emlékei Magyarországon. (clay gods. Records of the Neolithic and the copper age in Hungary) Budapest: Corvina Kiadó

Kennett D, Voorhies B (1995) Middle Holocene periodicities in rainfall inferred from oxygen and carbon isotopic fluctuations in prehistoric tropical estuarine mollusk shells. Archeometry 37:157-170

Koike H (1979) Seasonal dating and the valve-pairing technique in shellmidden analysis. J Archeol Sci 6:63-74

Kosse K (1979) Settlement ecology of the early and middle Neolithic Körös and linear pottery cultures in Hungary. Br Archeol Rep 64: 14-35

Krolopp E, Sümegi P (1995) Paleoecological reconstruction of the late pleistocene based on loess malacofauna in Hungary. GeoJournal 36: 213-222

Kuper R, Kropelin S (2006) Climate-controlled Holocene occupation in the Sahara: motor of Africa's evolution. Science 313:803-807

Kutzián I (1944) Körös-kultúra - the Körös culture. Dissertationes Pannonicae II./23:1-75

Langlet D, Alleman LY, Plisnier PD, Hughes H, André L (2006) Mn seasonal upwellings recorded in Lake Tanganyika mussels. Biogeosci Discuss 3:1453-1471

Langlet D, Alleman LY, Plisnier PD, Hughes H, André L (2007) Manganese content records seasonal upwelling in Lake Tanganyika mussels. Biogeosciences 4:195-203

Lazareth CE, Vander Putten E, André L, Dehairs F (2003) High resolution trace element profiles in shells of the mangrove bivalve Isognomon ephippium: a record of environmental spatio-temporal variations. Estuar Coast Shelf Sci 57:1103-1114

Lee GF, Wilson W (1969) Use of chemical composition of freshwater clamshells as indicators of paleohydrologic conditions. Ecology 50: 990-997

Legge AJ, Rowley-Conwy PA (1987) Gazella killing in Stone Age Syria. Sci Am 257:88-95

Leng MJ, Marshall JD (2004) Palaeoclimate interpretation of stable isotope data from lake sediment archives. Quat Sci Rev 23:811-831

Leonard RD, Jones GT (eds) (1989) Quantifying diversity in archeology. Cambridge University Press, Cambridge

Ložek V (1964) Quartermollusken der Tschechoslowakei. Rospravy Ustredniho Ustadu Geologickeho, Praha, p 31

Lyman RL (1994) Quantitative units and terminology in Zooarcheology. Am Antiq 59:36-71

Magny M (2004) Holocene climate variability as reflected by midEuropean lake-level fluctuations and its probable impact on prehistoric human settlements. Quat Int 113:65-79

Magny M, Begeot C, Guiot J, Marguet A, Billaud Y (2003) Reconstruction and palaeoclimatic interpretation of mid-Holocene vegetation and lake-level changes at Saint-Jorioz, Lake Annecy, French Pre-Alps. The Holocene 13:265-275

Makkay J, Starnini E (2008) The excavations of Early Neolithic sites of the Körös culture in the Körös valley, Hungary: the final report. Volume II: the pottery assemblages, and volume III: the small finds: figurines, reliefs, face vessels, handled cups, altars, loomweights, netweights, and other small finds., volume II. Budapest: Akadémiai Kiadó

McKenzie JA (1985) Carbon isotopes and productivity in the lacustrine and marine environment. In: Stumm WE (ed) Chemical processes in lakes. Wiley, New York

McKenzie JA, Hollander DJ (1993) Oxygen isotope record in recent carbonate sediments from Lake Greifen, Switzerland: application of continental isotopic indicator for evaluation of changes in climate and atmospheric circulation patterns. Climate change in continental isotopic records. Geophys Monogr 78:101-811

Meltzer DJ (2003) Lessons in landscape learning. In: Rockman M, Steele $\mathrm{J}$ (eds) Colonization of unfamiliar landscapes:the archeology of adaptation. Routledge, London \& New York, pp 222-241

Messerli B, Grosjean M, Hofer T, Nunez L, Pfister C (2000) From nature dominated to human dominated environmental changes. Quat Sci Rev 19:459-479

Moskal-del Hoyo M (2013) Mid-Holocene forests from eastern Hungary: new anthracological data. Rev Paleobotany Palynol 193:70-81

Moskal-del Hoyo M, Wachowiak M, Blanchette RA (2010) Preservation of fungi in charcoal. J Archaeol Sci 37:2106-2116

Mutvei H, Westermark T (2001) How environmental information can be obtained from naiad shells. In: Bauer G, Wachtler K (eds) Ecology and evolution of the freshwater mussels Unionidae. Springer, Berlin, pp 367-379

Nagaoka L (2002) The effects of resource depression on foraging efficiency, diet breadth, and patch use in southern New Zealand. J Anthropol Archaeol 21:419-442

Nagaoka L (2005) Declining foraging efficiency and moa carcass exploitation in southern New Zealand. J Archeol Sci 32:1328-1338

Nandris J (1972) Relation between the Mesolithic, the First Temperate Neolithic and the Bandkeramik: the nature of the problem. Alba Regia 12:61-70

Nichol RK, Wild CJ (1984) "Numbers of individuals" in faunal analysis: the decay of fish bone in archaeological sites. J Archeol Sci 11: $35-51$

Oross K, Bánnfy E (2009) Three successive ways of Neolithisation: LBK development in Transdanubia. Documenta Praehistorica 36:175-189

Oross K, Siklósi ZS (2010) Relative and absolute chronology of the Early Neolithic in the Great Hungarian Plain. In: Gronenborg D, Petrasch J (eds) The spread of the Neolithic to Central Europe. Verlag des RGZM, Mainz, pp 129-159

Peacock E, Seltzer JE (2008) A comparison of multiple proxy data sets for paleoenvironmental conditions as derived from freshwater bivalve (Unionid) shell. J Archaeol Sci 35:2557-2565

Pearson JA, Hedges REM (2007) Stable carbon and nitrogen isotope analysis and the evidence for diet at Ecsegfalva and beyond. In: Whittle A (ed) The Early Neolithic in the Great Hungarian Plain: investigations of the Körös culture site of Ecsegfalva 23, Békés County. HAS Institute of Archeology, Budapest, pp 413-421

Peterson ML (1989) Marine invertebrate analysis of CA-SLO-165: quantification, measurement theory, formation and ecological history. Report for Singer and Associates, California

Pfister C (2001) Klimawandel in der Geschichte Europas. Zur Entwicklung und zum Potenzial der historischen klimatologie Österische Zeitschrift für Gesichtswissenschaften 12:7-42

Pfister C, Brazdil R (2006) Social vulnerability to climate in the 'Little Ice Age': an example from Central Europe in the early 1770s. Clim Past 2:115-129 
Pfister C, Brazdil R, Glaser R. (eds) (1999). Climatic variability in 16th century Europe and its social dimension. Climate Change special edition, 278.

Pike-Tay A, Bartosiewicz L, Gál E, Whittle A (2004) Body part representation and seasonality: sheep/goat,bird and fish remains from Early Neolithic Ecsegfalva 23, SE Hungary. J Taphonomy 2:221222

Plug I, Voight EA (1985) Archeozoological studies of Iron Age communities in southern Africa. Adv World Archeol 4:189-238

Polyak VJ, Asmerom Y (2001) Late Holocene climate and cultural changes in the southwestern United States. Science 294:148-151

Pradyot P (2004) Dean's analytical chemistry handbook, 2nd edn. McGraw-Hill, New York

Raczky P (1978) A Körös-kultúra figurális ábrázolásai Nagykörüből — Figurale Darstellungen der Körös-Kultur aus Nagykörü. Szolnok Megyei Múzeumi Évkönyv 1978:7-17

Raczky P (1983) A kora neolitikumból a középső neolitikumba való átmenet kérdései a Közép-és Felső Tiszavidéken. (problems of the early to middle Neolithic transition in the middle and upper Tisza region). Archeologiai Értesitő 110:161-194

Raczky P (1986) Megjegyzések az "alföldi vonaldíszes kerámia" kialakulásának kérdéséhez (Remarks to the aspects of the evolution of the AVK). Régészeti tanulmányok Kelet-Magyarországról Folklór és Etnográfia 24:45-59

Raczky P (2012) Nagykörü-Tsz Gyümölcsös (co-operative orchard), in: the first Neolithic sites in central/south-east European transect, Vol. III - the Körös culture in eastern Hungary, Anders A., Siklósi Zs. (eds.), BAR International Series 2334, Archaeopress, Oxford, pp.97-105

Raczky P, Sümegi P, Bartosiewicz L, Gaál E, Kaczanowska M, Kozłowski JK, Anders A (2010) Ecological barrier versus mental marginal zone? Problems of the northernmost Körös Culture settlements in the Great Hungarian Plain. In: Gronenborg D, Petrasch J (eds) The spread of the Neolithic to Central Europe. Verlag des RGZM, Mainz, pp 147-175

Ravera O, Cenci R, Beone GM, Dantas M, Lodigiani P (2003) Trace element concentrations in freshwater mussels and macrophytes as related to those in their environment. J Limnol 62(1):61-70

Ravera O, Beone GM, Trincherini PR, Riccardi N (2007) Seasonal variations in metal content of two Unio pictorum mancus populations from two lakes of different trophic state. J Limnol 66:28-39

Redman CL (2005) Resilience theory in archaeology. Am Anthropol 107(1):70-77

Reimer PJ, Bard E, Bayliss A, Beck JW, Blackwell PG, Bronk-Ramsey C, Buck CE, Cheng H, Edwards RL, Friedrich M, Grootes PM, Guilderson TP, Haflidason H, Hajdas I, Hatte C, Heaton TJ, Hogg AG, Hughen KA, Kaiser KF, Kromer B, Manning SW, Niu M, Reimer RW, Richards DA, Scott EM, Southon JR, Turney CSM, van der Plicht J (2014) IntCal13 and MARINE13 radiocarbon age calibration curves 0-50000 years cal BP. Radiocarbon 55:18691887

Richardson LL, Aguilar C, Nealson KH (1988) Manganese oxidation in $\mathrm{pH}$ and $\mathrm{O}_{2}$ microenvironments produced by phytoplankton. Limnol Oceanogr 33:352-363

Ricken W, Steuber T, Freitag H, Hirschfeld M, Niedenzu B (2003) Recent and historical discharge of a large European water systemoxygen isotopic composition of river water and skeletal aragonite of Unionidae in the Rhine. Palaeogeogr Palaeoclimatol Palaeoecol 193:73-86

Roberts N (1998) Holocene. In: An environmental history. Blackwell Publishers, Oxford

Rockman M (2003) Knowledge and learning in the archeology of colonization. In: Rockman M, Steele J (eds) Colonization of unfamiliar landscapes:the archeology of adaptation. Routledge, London \& New York, pp 3-24
Rustioni M, Mazza P, Magnatti M (2007) Multivariable analysis of an Italian Late Neolithic archaeofauna. J Archaeol Sci 34:723-738

Salisbury RB, Bácsmegi G (2013) Resilience in the Neolithic: how people may have mitigated environmental change in prehistory. Anthropologie 51(2):143-155

Sebilo M, Billen G, Grably M, Mariotti A (2003) Isotopic composition of nitrate-nitrogen as a marker of riparian and benthic denitrification at the scale of the whole Seine River system. Biochemistry 63:35-51

Sherratt A (1982) The development of Neolithic and Copper Age settlement in the Great Hungarian Plain. Part I and II. The regional setting; site survey and settlement dinamics. Oxford J Archeol 1: 287-316

Siegele R, Orlic I, Cohen DD, Markich SJ, Jeffree RA (2001) Manganese profiles in freshwater mussel shells. Bull Nucl Instrum Methods Physics Res 181:593-597

Sokal RR, Rohlf FJ (1995) Biometry. Freeman Publishers, New York

Speth JD (1990) Seasonality, resource stress, and food sharing in socalled "egalitarian" foraging societies. J Anthropol Archeol 9: $148-188$

Spielmann KA (1986) Interdependence among egalitarian societies. J Anthropol Archeol 5:279-312

Spurk M, Leuschner HH, Baillie MGL, Briffa KR, Friedrich M (2002) Depositional frequency of German subfossil oaks: climatically and non-climatically induced fluctuations in the Holocene. The Holocene 12(6):707-715

Strien HC, Gronenborn D (2005) Klima- und Kulturwandel während des mitteleuropäischen Altneolithikums (58./57.-51./50. Jahrhundert v. Chr.). In: Gronenborn D (ed.) Klimaveränderung und Kulturwandel in neolithischen Gesellschaften Mitteleuropas, 6700-2200 v. Chr. Mainz: RGZM - Tagungen 1. Verlag des Römisch-Germanischen Zentralmuseums, pp.131-150

Stumm WM, Morgan JJ (1996) Aquatic chemistry. John-Wiley, New York

Sümegi P (1989) A Hajdúság felső-pleisztocén fejlődéstörténete finomrétegtani (őslénytani, szedimentológiai) vizsgálatok alapján (The evolution of the area of the Hajdúság during the Upper Pleistocene). unpublished $\mathrm{PhD}$ thesis, Debrecen: University of Debrecen

Sümegi P (2001) A negyedidőszak földtanának és őskörnyezettanának alapjai. JATEPress, Szeged

Sümegi P (2003a) Régészeti geológia és történeti ökológia alapjai. (An introduction to geoarcheology and historical ecology). JATEPress, Szeged

Sümegi P (2003b) Early Neolithic man and riparian environment in the Carpathian Basin. In: Jerem E, Raczky P (eds) Morgenrot der Kulturen. Archaeoligua Press, Budapest, pp 53-60

Sümegi P (2004) Environmental changes under the neolithization process in Central Europe: before and after. Anthaeus 27:117-128

Sümegi P (2006) Paleogeographical background of the Mesolithic, Early Neolithic settlements in the Carpathian Basin. Proceedings of the 15th UISPP Congress, Lisboa, pp 47-51

Sümegi P (2007) Mollusc-based reconstruction around the area of the Kiri-tó. In: Whittle A (ed) The Early Neolithic in the Great Hungarian Plain: investigations of the Körös culture site of Ecsegfalva 23, Békés County. MTA Institute of Archeology, Budapest, pp 109-123

Sümegi P (2008) Magyarország negyedidőszak végi környezettörténete: Az elmúlt 34 ezer év üledékföldtani és malakológiai változásai Magyarországon. (the environmental history of the terminal part of the Quaternary in Hungary for the past 34 kys in the light of sedimentological and malacological investigations). Unpublished DSc thesis to the Hungarian Academy of Science: Szeged-Budapest, 545

Sümegi P, Kertész R (1998) Ablak az időre. Ember és környezet kapcsolata a Kárpát-medencében az időtudományok tükrében. (A window to time. Man and environment in the Carpathian Basin from the view of time) Szolnoki Tudományos Közlemények 1:66-69 
Sümegi P, Kertész R (2001) Palaeogeographic characteristics of the Carpathian Basin - an ecological trap during the Early Neolithic? In: Kertész R, Makkay J. (eds.) from the Mesolithic to the Neolithic. Proceedings of the International Archaeological Conference held in Szolnok 1996: Budapest, 405-415

Sümegi P, Krolopp E (2002) Quartermalacological analyses for modeling of the Upper Weichselian palaeoenvironmental changes in the Carpathian Basin. Quat Int 91:53-63

Sümegi P, Molnár S (2007) The Kiritó meander: sediments and the question of flooding. In: Whittle A (ed) The Early Neolithic in the Great Hungarian Plain: investigations of the Körös culture site of Ecsegfalva 23, Békés County. MTA Institute of Archeology, Budapest, pp 67-82

Sümegi P, Csökmei B, Persaits G (2005) The evolution of Polgár Island, A loess covered lag surface and its influences on the subsistence of settling human cultural groups. In: Hum L, Gulyás S, Sümegi $\mathrm{P}$ (eds) Environmental historical studies from the late tertiary and quaternary of Hungary. University of Szeged, Szeged, pp 141-163

Sümegi P, Gulyás S, Persaits G (2012) Magyarország környezettörténete: ember és környezet hosszú távú kapcsolata a Kárpát-medencében. Példa az alluviális löszös szigetek kora neolit hasznosítására (Nagykörü - TSz Gyümölcsös) Environmental history of Hungary: long time connection between man and environment in the Carpathian Basin. An instance for Early Neolithic economy on the loess covered alluvial island (Nagykörü - Tsz Gyümölcsös site) In: Kreiter A, Pethő Á, Tugya B (eds): Környezet-ember-kultúra: a természettudományok és a régészet párbeszéde. (Environmenthumans-culture: a dialogue of natural sciences and archeology) KEK Magyar Nemzeti Múzeum Örökségvédelmi Központ, Budapest, pp.115-125

Szöör GY, Balázs É, Cserháti CS, Dinya Z, Hertelendi E, Sümegi P, Szanyi J (1992) Quarter és Neogén mollusca-héjak kemotaxonómiai és paleoökológiai elemzése. In: Szöőr GY (ed) Fáciesanalitikai, paleobiogeokémiai és paleoökológiai kutatások. MTA Debreceni Akadémiai Bizottság, Debrecen, pp 111-183

Szuter CR, Bayham FE (1989) Sedentism and prehistoric animal procurement among desert horticulturalists of the North American Southwest. In: Kent S (ed) Farmer as hunters: the implications of sedentism. Cambridge University Press, Cambridge, pp 80-95

Törő́csik T, Gulyás S, Sümegi P, Sümegi BP, Molnár D, BenyóKorcsmáros R (2019) Environmental history of the Csorna plain (Western Danube Plain, NW Hungary) from the Late Glacial to the Late Holocene as seen from data of multiproxy geoarchaeological investigations. Studia Quaternaria 36(1):19-43. https://doi.org/10.24425/sq.2019.126377

Tripati A, Zachos J, Marinkovich L Jr, Bice K (2001) Late Paleoecene artic coaastal climate inferred from molluscan stable and radiogenic isotope ratios. Paleos 179:101-113

Vander Putten E, Dehairs F, Keppens E, Baeyens W (2000) High resolution distribution of trace elements in the calcite shell of modern Mytilus edulis: environmental and biological controls. Acta Geochimica et Cosmochemica 64:997-1011
Versteegh EAA (2008) Stable oxygen isotopes in freshwater mussels (Unionidae) as a proxy for late Holocene floods and droughts of Rhine and Meuse. Geophys Res Abstr 10:10-45

Weiberg E, Finné M (2018) Resilience and persistence of ancient societies in the face of climate change: a case study from late bronze age Peloponnese. J World Archaeol. 50(4): vulnerability, risk and resilience: $584-602$

Weninger B, Alram-Stern E, Bauer E, Clare L, Danzeglocke U, Jöris C, Kubatzki C, Rollefson G, Todorova H, van Andel T (2006) Climate forcing due to the $8200 \mathrm{cal} \mathrm{BP}$ event observed at early neolithic sites in the eastern Mediterranean. Quat Res 66:401-420

Whittle A (2004) Connections in the Körös culture world: exchange as an organising principle. Antaeus 27:17-26

Whittle A (ed) (2007) The Early Neolithic in the Great Hungarian Plain: investigations of the Körös culture site of Ecsegfalva 23, Békés County. HAS Institute of Archeology, Budapest

Whittle, AWR (2012) El Neolítico en Europa: cuestión de escala y tempo. In: Rojo Guerra, M., Garrido Pena, R. and Garcia Marti nez de Lagran, I. (eds.) El Neolítico en la Península Ibéerica y su Contexto Europeo. Madrid: Cátedra, pp. 13-26

Whittle A, Bartosiewicz L, Borić D, Pettitt P, Richards M (2002) In the beginning: radiocarbon dates from the Early Neolithic in northen Serbia and south-east Hungary. Antaeus 25:63-117

Willis KJ (2007) The impact of the Early Neolithic Körös culture on the landscape: evidence from paleoecological investigations of the Kiritó. In: Whittle A (ed) The Early Neolithic in the Great Hungarian Plain: investigations of the Körös culture site of Ecsegfalva 23, Békés County. HAS Institute of Archeology, Budapest, pp 83-99

Windland P (2007) The phytoliths of the Kiri-tó. In: Whittle A (ed) the Early Neolithic in the Great Hungarian Plain: investigations of the Körös culture site of Ecsegfalva 23, Békés County. HAS Institute of Archeology, Budapest, pp 99-109

Wolverton S (2005) The effects of the hypsithermal on prehistoric forgaing efficiency in Missouri. Am Antiq 70:91-106

Xu A, Yang LE, Yang W, Hillman AL (2019) Resilience of the humanwater system at the southern Silk Road: a case study of the northern catchment of Erhai Lake, China (1382-1912). In: SocioEnvironmental Dynamics along the Historical Silk Road. Springer, Cham, pp 325-358

Yang LE, Bork HR, Fang X, Mischke S, Weinelt M, Wiesehöfer J (2019) On the paleo-climatic/environmental impacts and socio-cultural system resilience along the historical Silk Road. In: Yang et al (eds) Socio-Environmental Dynamics along the Historical Silk Road. Springer, Cham, pp 3-22

Zvelebil M, Dolukhanov P (1991) The transition to farming in eastern northern Europe. J World Prehist 5:233-278

Publisher's note Springer Nature remains neutral with regard to jurisdictional claims in published maps and institutional affiliations. 